This is a self-archived - parallel published version of this article in the publication archive of the University of Vaasa. It might differ from the original.

\title{
Modern mediators: intermediaries' informational roles in sourcing from China
}

Author(s): Virtanen, Yuan; Salmi, Asta; Qin, Xiao

Title: Modern mediators: intermediaries' informational roles in sourcing from China

Year: $\quad 2021$

Version: Accepted version

Copyright C2021 Emerald Publishing Limited. This manuscript version is made available under the Creative Commons AttributionNonCommercial 4.0 International (CC BY-NC 4.0) license, https://creativecommons.org/licenses/by-nc/4.o/

Please cite the original version:

Virtanen, Y., Salmi, A. \& Qin, X. (2021). Modern mediators: intermediaries' informational roles in sourcing from China. Journal of Business and Industrial Marketing. https://doi.org/10.1108/JBIM-03-2021-0172 
Journal of Business \& Industrial Marketing (JBIM)

Forthcoming, article publication on line November 16, 2021

https://doi.org/10.1108/JBIM-03-2021-0172

\title{
Modern mediators: \\ Intermediaries' informational roles in sourcing from China
}

\author{
Yuan Virtanen ${ }^{1}$ \\ Asta Salmi ${ }^{2}$ \\ Xiao Qin ${ }^{3}$
}

\begin{abstract}
Purpose - Sourcing intermediaries, commonly known as agents or trading companies, represent a useful organisational solution for assisting companies to manage supply risks and to overcome the liability of foreignness. However, the landscape of global business is experiencing rapid and fundamental changes, which leads us to ask whether intermediaries will continue to play a role in global sourcing. This paper aims to understand how sourcing intermediaries ensure a lasting position in the changing setting of global sourcing and information sharing.
\end{abstract}

Design/methodology/approach - This paper investigates the operations of both Chinese and Nordic (Finnish and Swedish) intermediaries in sourcing from China by analysing qualitative data collected over a period of four years.

Findings - Through the lens of information asymmetry, this paper identifies four distinct informational roles that are employed by intermediaries to reduce information asymmetry between suppliers and buyers located in different countries. The paper also examines intermediaries' signalling activities under these roles in a cross-border triad.

Originality - The paper contributes to the scientific debate on the usefulness of intermediaries by underlining intermediaries' informational advantage, which provides a new explanation for the survival of intermediaries in a rapidly changing business context. Additionally, this study contributes to research on intermediation strategies by empirically examining both Chinese and Western intermediaries, highlighting the importance of institutional contexts in affecting intermediaries' informational roles.

Keywords: Intermediary, Sourcing intermediary, Trading company, Global sourcing, China, Qualitative research

\footnotetext{
${ }^{1}$ School of Intelligent Finance and Business, Entrepreneur College, Xi'an Jiaotong-Liverpool University, Suzhou, China

${ }^{2}$ School of Marketing and Communication, University of Vaasa, Vaasa, Finland

${ }^{3}$ School of Digital Commerce, Nanjing Vocational College of Information Technology, Nanjing, China
} 


\section{Introduction}

Today it's not enough to say, 'I have a supplier in China, would you like to buy from us?' You have to add much more to your product.

A Nordic intermediary in 2018

I can only see that our role as an intermediary has strengthened during the last year.

A Nordic intermediary in 2021

Intermediaries - such as trading companies, agents and merchants - have played a key role in international business for centuries (Ellis, 2003; Nassimbeni and Sartor, 2007). Intermediaries of many types represent a valuable organisational solution to facilitating world trade by connecting distant buyers and sellers across international boundaries and helping in assisting companies to overcome their foreignness by offering better local knowledge and access to local business relationships and networks (Johanson and Vahlne, 1977; Li, 2003; Nassimbeni and Sartor, 2007). However, the landscape of global business is experiencing rapid and fundamental changes (Petricevic and Teece, 2019; Witt et al., 2021; Ancarani et al., 2021). Driven by the deteriorating cost advantages of some low-cost countries (Fang et al., 2010) and the 'hidden costs of offshoring' (Larsen et al., 2013), firms from high-cost countries have relocated manufacturing back to their home countries, a phenomenon commonly known as backshoring (Fratocchi et al., 2016). The present COVID-19 crisis further accelerates the pace of deglobalisation (Witt, 2019b; Witt et al., 2021) by unveiling fears of dependency on key exporting countries, such as China, for strategic supplies (Gereffi, 2020). On the other hand, geographical separation and cultural distance are noted to have become less salient in firms' international expansion due to the advancement of 
information technology and culture's all-dimensional learning over time (Fang et al., 2017), which significantly diminishes the information asymmetry that intermediaries traditionally rely upon (Ellis, 2003). These fundamental changes in global business lead us to ask whether intermediaries still play a role in global sourcing.

As one of the most enduring organisational forms in business history, intermediaries have repeatedly risen to the occasion by adapting their role to a precarious business world that is not changing to their advantage (Ellis, 2001; Peng and York, 2001). Investigations of the adaptive characteristics of intermediaries' functions (Perry, 1990; Ellis, 2001) were performed several decades ago and are somewhat limited to the industry, country and/or time in which the research was conducted. Thus, we do not know what kind of role today's intermediaries play and which intermediary activities are crucial in response to the more recent social, economic and political changes. Understanding intermediaries' unique capabilities that are associated with longevity will enhance our knowledge about organisational survival in general.

Furthermore, extant studies have taken a dyadic perspective and focused on control-based mechanisms to curb intermediaries' opportunistic behaviour in, for instance, an exporterintermediary dyad (Karunaratna and Johnson, 1997). Thus, they offer limited insight into intermediaries' proactive behaviour in resolving informational conflicts in a triadic relationship which involves geographically dispersed buyers and suppliers. A focus on all the involved parties is important because intermediaries are naturally situated in a triadic relationship where both suppliers and buyers have the power to impact on the very existence of the intermediaries (Havila et al., 2004).

Somewhat surprisingly, intermediary studies seldom consider the complexities caused by the international context. Therefore, issues such as geographical and cultural distance are mostly 
ignored, with the exception of some examination of the Sino-Western context in particular (Salmi, 2006; Nassimbeni and Sartor, 2007; Jia et al., 2014b). These studies, however, have primarily taken the perspective of Western intermediaries. An investigation into both Western and Chinese intermediaries, as well as the impact of institutional contexts on their operations, is thus lacking. In order to address these gaps, this study aims to understand how contemporary intermediaries ensure a lasting position in the changing setting of global sourcing and information sharing. We focus on the informational roles of intermediaries in reducing information asymmetries and improving the information flow between Chinese suppliers and European (Nordic) buyers. In addition, we discuss signals that intermediaries use in these roles. The key research question guiding our research is: 'What kind of informational roles do sourcing intermediaries adopt in contemporary Chinese sourcing?'

To answer this research question, we investigate operations of both Chinese and Nordic (Finnish and Swedish) intermediaries. The key data source is a collection of in-depth interviews with Chinese and Nordic intermediaries that are sourcing from China and operating in China and Europe, respectively, as well as interviews with companies related to these intermediaries.

The paper is structured as follows. After this introduction, we review literature on intermediaries' activities in global sourcing and in sourcing from China and on information asymmetry in relation to the intermediary as a moderator between the buyer and seller, as well as literature on using signalling as a tool to reduce information asymmetry. These discussions are summarised in the initial framework for the study. Then, the methodology of the study is discussed. The subsequent section presents our empirical findings and shows the four key informational roles performed by the intermediary. The discussion and conclusion sections provide our conceptual contribution, as well as the managerial implications and future research directions. 


\section{Theoretical background}

\section{Intermediaries in global sourcing and in sourcing from China}

In the process models of global sourcing, intermediaries represent the initial stage of development and eventually become redundant along with firms' increasing global experience and industry maturity (Monczka and Trent, 1991; Nassimbeni and Sartor, 2007; Jia et al., 2014b). Consequently, international business studies tend to focus on more advanced operation modes, disregarding analysis of intermediaries and agents in value chains. Some scholars have, however, begun to challenge such disintermediation views by highlighting intermediaries' adaptive strategies to remain valuable (Ellis, 2001; Peng and York, 2001). Indeed, the literature shows that sourcing intermediaries take on many, often complicated activities and various roles in order to sustain their position in the global value chains (please see Appendix 1 for an illustrative list of these activities and Appendix 2 for examples of the diverse roles intermediaries play as described in the extant literature ${ }^{4}$ ). However, as these studies were conducted at least a decade ago (in some cases, decades ago), a question remains about whether new activities of intermediaries have emerged in response to the changing environment.

Of all global sourcing destinations, China has attracted significant scholarly interest due to its position as the 'world factory' (Zhang, 2006). Nevertheless, distance still matters in international business (Petricevic and Teece, 2019), and from a Western and Nordic perspective, China is a faraway market, not only geographically but also in terms of psychic distance (Johanson and Vahlne, 1977). Because China represents a 'relationship-focused' culture (Giannakis et al., 2012;

\footnotetext{
${ }^{4}$ Given space limitations and the primary objective of this paper, the works covered in Appendix 1 and Appendix 2 are not intended to be comprehensive. Instead, only the most salient studies are presented to show the diversity of intermediary activities and roles.
} 
Jia et al., 2014a; Huo et al., 2018), establishing and maintaining interpersonal and interorganisational relationships is particularly important for business there. However, not all companies are equipped with local knowledge, nor do they have the resources to invest in longterm relationship building. Intermediaries have offered an important solution for dealing with such problems, and they are an ideal option for small companies with limited resources (Nassimbeni and Sartor, 2007). These findings suggest that while foreign companies may face psychic distance - that is, factors preventing the flow of information from/to the market (Johanson and Vahlne, 1977) - they can avoid the liability of outsidership (Johanson and Vahlne, 2009) by building a relationship with an intermediary. Our study therefore focuses on the activities and advantages that intermediaries that are embedded in relevant Chinese networks have in advancing information flows in sourcing.

Since the opening-up reform in the late 1970s, China has been experiencing significant social, economic and political transitions (Jia et al., 2014b; Huo et al., 2018). In the 2000s, Chinese foreign trade policies changed remarkably and, as a result, Chinese public foreign trade companies lost their foreign trade monopoly and private manufacturers were able to trade directly with foreign buyers (Nassimbeni and Sartor, 2007). These changes gave new options for foreign buyers in their Chinese sourcing. Further dynamics are caused by two global trends which are influencing global value chains - and therefore, potentially intermediaries - in sourcing from China. The first trend concerns deglobalisation and decoupling processes in global value chains (Witt, 2019b). These ongoing changes, linked to geopolitics and thus to the role of China and Chinese firms in global business, are raising the need for the re-evaluation of global supply chains as well (Witt, 2019a; Witt et al., 2021). The COVID-19 pandemic is bound to strengthen deglobalisation, leading to new restrictions on mobility and disruptions in value chains (Delios et al., 2021). The other trend relates 
to digitalisation and the development of information communication technology (ICT). Indeed, advancements in ICT and e-commerce have gradually diminished the information asymmetry that intermediaries traditionally rely upon (Peng and York, 2001). Therefore, it becomes relevant to ask how intermediaries may survive in a rapidly changing business world which is not changing to their advantage.

\section{Information asymmetry and the role of intermediaries}

Information, especially the transparency and quality of information flows, represents a crucial factor in managing firms' global supply chains (Popp, 2000). Information costs are generated by the process of collecting, communicating and storing information (Casson, 1997). One of the principal sources of information costs is information asymmetry, a situation where one party has information the other desires and does not have (Lassar and Kerr, 1996). In the context of a buyersupplier relationship, this lack of knowledge reciprocity typically brings informational disadvantages to the buyers as the suppliers possess more and better information about their products and services (Akerlof, 1970). In an international encounter (and especially when complex product deliveries are involved), geographical and cultural distances bring about additional uncertainty between partners, which may aggravate the information asymmetry already embedded in buyer-supplier relationships and lead to contractual inefficiencies (Solberg, 2008; Vedel and Ellegaard, 2013).

Two types of problem arise as a result of information asymmetry: adverse selection and moral hazards (Mavlanova et al., 2012). The former, also known as hidden information or precontractual problems, refers to a situation where it is difficult or expensive to verify the prospective supplier's shortcomings and true qualifications (i.e. whether the supplier has the characteristics the buyer is looking for) (Jensen and Meckling, 1976). Moral hazards, also referred 
to as hidden action or post-contractual problems, occur post-contractually when the supplier's efforts are not consistent with the requirements of the buyer (Bergen et al., 1992).

One way to solve information problems when entering distant markets is to employ foreign-based intermediaries who have superior information of local markets (Giunipero and Monczka, 1990). With their unique tertius iungens ('third who joins') position at the intersection of buyer-supplier relationships, trading intermediaries play a vital role in minimising information costs by improving the quality of and reducing the quantity of the information exchanged (Casson, 1997). Paradoxically, hiring a foreign-based intermediary itself poses questions about trust and goal congruence (Popp, 2000). Because of self-interest, intermediaries may deliberately distort or disguise information passed along the channel (Ellis, 2003), and they may be therefore seen as an extra, burdening link in the information chain and a source of information asymmetry (Popp, 2000). In fact, the informational role of the intermediary may designate that its services may eventually become redundant when the intermediary successfully increases the understanding of the buying firm and its supplier, leading to the 'trader's dilemma' phenomenon (Ellis, 2005).

In order to overcome the hidden information problem in the pre-contractual stage, intermediaries may engage in actions aimed at signalling their honesty and abilities to the customers (Peng and York, 2001). Signals are alterable and visible attributes designed to convey information about firms' unobservable characteristics to the signal receivers (Bergen et al., 1992). The bestperforming intermediaries are likely to possess the best signalling capabilities, which are achieved through the outcome and/or behavioural means (Peng and York, 2001). An outcome-based signal is taking title to the goods. Such an arrangement achieves the complete alignment of interests of both parties by transforming the potential risk of financial loss to the intermediary (Peng and York, 
2001). A behavioural signal is specialising in simple commodity-based products because these are less costly to monitor and contracts are easier to enforce (Peng et al., 2000).

\section{Analytic framework: Intermediaries' informational role in global sourcing}

This explorative study set out to analyse intermediaries operating in the triadic setting between buyers and suppliers in sourcing from China. Figure 1 presents our analytic framework, which guides and structures our empirical (inductive) study.

Insert Figure 1 about here

To start with, we see that intermediation is needed to cover the psychic distance (Johanson and Vahlne, 1977) between the business partners where, for example, cultural aspects may be a barrier for information flows. A key task for intermediaries is to address the information asymmetry prevailing between buyers and sellers. Such asymmetries may appear in the pre-contract and postcontract phases of business. We aim at exploring the activities that intermediaries perform and we focus on the question of their sharing information within the triad, as well as their signalling about their intrinsic value in the triad.

In addition, we look at the issue of whether the intermediary may hold a lasting position, and if so, how they may do so. The continuity of the position of the intermediary (in other words, the enduring need for its services between the buyer and seller) is addressed here from two perspectives. First, the intermediary and its services become potentially redundant if the buyer and seller learn about each other and choose to establish a direct relationship, thus bypassing the intermediary. This trader's dilemma (Ellis, 2005) is illustrated in Figure 1 by the dotted arrow that indicates the potentially emerging direct relationship between the buyer and the seller. Second, 
global trends - such as deglobalisation, the decoupling of value chains and companies' strategic choices to backshore, as well as reduced information asymmetry due to cultural learning and the development of information technology - may cause more generic pressures, hampering the role of and need for intermediaries.

\section{Methodology}

\section{The qualitative approach and sampling}

As the study seeks an in-depth understanding of the informational role of intermediaries in sourcing from China and as the extant literature offers limited insights into this contemporary phenomenon, we adopted a qualitative approach, which emphasise depth and exploration (Ellram, 1996), and utilise several data sources. Furthermore, the interviews of both the Nordic and Chinese actors were conducted by a person who is familiar with both cultural contexts. Our study thus addresses the calls for applying qualitative and emic approaches in international business studies (Tung and Stahl, 2018).

Our unit of analysis is formed of international sourcing intermediaries' informational activities and the signalling of their role in intermediation. We aimed for a revelatory global sourcing setting and focused on Western companies' sourcing from China by investigating both Chinese and Nordic intermediaries. China represents a typical high-context culture, different from the Nordic low-context culture (Ramstrom, 2008; Giannakis et al., 2012). Therefore, we assume that in the Sino-Nordic context, sourcing intermediaries will take on interesting and complex roles. To demonstrate the diversity of the predicted outcomes (Patton, 2002), we aimed at reaching companies that vary in terms of size, industry, ownership type, product ownership and channel 
focus. A comparison between the sampled Nordic and Chinese intermediaries is summarised in Table I.

Insert Table I about here

We followed two different routes in selecting companies for the study. For the Nordic companies, we started by searching web pages to find intermediaries that offer services for sourcing from China. We contacted several companies and a Swedish intermediary, M1(SE), was the first to respond. Through M1(SE), we gained access to a Finnish intermediary, M2(FI), a former franchisee of M1(SE). Through the recommendation from M2(FI), we reached the Finnish intermediary M3(FI). All three intermediaries are small private companies and the products involved vary from consumer products to industrial components. In the second interview round, we relied on the same search method and widened the circle of contacted intermediaries. In addition, we contacted one Swedish buyer, which was served by the Swedish intermediary M1(SE), as well as a buyer in Finland served by M4(FI). The selection process thus featured the convenience sampling technique and, partly, the snowball sampling technique (Eriksson and Kovalainen, 2008: 52). This is justified by the fact that sourcing intermediaries are often inaccessible through directories and the industry is characterised by interconnected relationships (Vedel and Ellegaard, 2013).

As the second step of our empirical study, we reached out for Chinese intermediaries. In this setting, we had to take a different route for finding and selecting respondents. Following the cultural norms and network-based business context (Ramstrom, 2008; Tsang, 1998), we relied on the personal networks of a local scholar (the third author of this study) to gain access to Chinese intermediaries. This person helped in finding intermediaries serving the Western markets and 
participated in all of the interviews conducted in China. The majority of these Chinese intermediaries are large state-owned companies due to the fact that prior to the early $2000 \mathrm{~s}$ all trading intermediaries in China were state-owned (thus, large) public foreign trade companies (Nassimbeni and Sartor, 2007). The resulting sample of selected Chinese companies (using code names to ensure anonymity) and information on the interviews are summarised in Table II.

\section{Insert Table II about here}

We intended to include multiple voices, representing various members of the supply chains. However, information on specific suppliers and buyers directly relates to intermediaries' perceived competitive advantages and is thus sensitive by nature (Vedel and Ellegaard, 2013); we were not able to reach different tiers of supply chains or detailed information on specific buyer-seller relationships. Obviously, had we been able to, this would have contributed to a better contextual understanding of the actors and relationships. Still, we succeeded in addressing a diverse set of middlemen and observed different partnerships maintained by the intermediaries. Moreover, we have information on three sets of direct partners: the Swedish intermediary M1(SE) was serving the Swedish company B1(SE), the Finnish intermediary M4(FI) was serving the Finnish company B2(FI) and the Finnish intermediary M2(FI) was working with the Chinese supplier S1(CN).

In order to increase the validity of the results, we interviewed experienced respondents who possess key roles in their company (e.g. they were the CEO, COO, managing director or purchasing manager) and are familiar with the company's global sourcing strategies. Some complementary questions were posed to the interviewees by emails or phone calls in the data analysis phase to clarify emerging issues. To increase reliability and to provide a formal assembly of evidence (Ellram, 1996), we have created a database for the study that includes all the interview 
transcripts, coded transcripts with notes for each interview, lists of codes and company archival data.

\section{Data collection}

In order to have a comprehensive view of the companies and to triangulate the data, we used multiple sources of evidence (Yin, 2009). Our data set consists of both primary data (in-depth interviews and email exchanges) and secondary data (including company websites, company documents and news articles). The primary data was collected through 23 semi-structured interviews (lasting one to four hours per interview) with 17 respondents (six Nordic intermediaries, seven Chinese intermediaries, one supplier, two buyers and one industry expert). The major advantage of semi-structured interviews is that the materials are somewhat systematic and comprehensive, while the tone of the interview is fairly conversational and informal (Eriksson and Kovalainen, 2008). In line with the explorative nature of the study, we created an interview protocol to help us keep interactions focused, yet allowing individual perspectives and experiences to emerge (Patton, 2002). Table III presents the data sources for the study.

\section{Insert Table III about here}

The first round of data collection took place in 2015 when we interviewed the Nordic intermediaries M1(SE), M2(FI) and M3(FI). The last two of these intermediaries were interviewed twice to gain enough data. Moreover, we interviewed a Chinese supplier S1(CN) (twice) to better understand the Chinese context for sourcing. $\mathrm{S} 1(\mathrm{CN})$ is the major supplier of M2(FI) and is specialised in industrial components. To enrich our data, we conducted a second round of interviews in 2017. At this point, we approached M1(SE) and M3(FI) again, as well as added three 
more intermediaries: M4(FI), M5(FI) and M6(FI). Moreover, we interviewed two Nordic buyers to add views on the needs of buyers in Chinese sourcing. After performing our initial analysis of the Nordic data, we extended our analysis to also include Chinese intermediaries in a third round of data collection in 2018. We interviewed seven Chinese intermediaries and one Chinese industry expert, E1(CN). At this point, we had reached the theoretical saturation point (Glaser and Strauss, 1967) as we found convergence of the views of the respondents, and we saw that additional information was not needed to enhance our understanding of the core issue. Finally, we added to our understanding of ongoing changes by approaching key companies again in 2021 . Then, two intermediaries, $\mathrm{M} 1(\mathrm{SE})$ and $\mathrm{M} 4(\mathrm{FI})$, and the Chinese expert E1(CN) were approached by email to ask about their views of the impacts of COVID-19 and deglobalisation. At this point, a personal interview was also conducted with our key informant M1(SE).

In the interviews, we did not explicitly ask about information asymmetry or signalling as we considered the terms potentially limiting and relatively theoretical, and therefore potential sources for misunderstanding by the respondents. Instead, we asked the respondents to describe intermediary activities that add value or improve buyer-supplier relationships. The interview guide is presented in Appendix 3.

The first author, who is native Chinese and fluent in English, conducted the interviews in Chinese or English based on the interviewees' preference. Most of the interviews were electronically recorded with the permission of the interviewees. In the case of the interviewee declining to have the interview recorded, the interviewer made written notes about the interview. The interviews were then transcribed verbatim and translated (when needed) into English by the first author. Analysis of the data was carried out jointly on the basis of these English interview transcripts. 
The secondary data first served as background information to help us identify potential respondents, prepare for interviews and build initial company descriptions. Intermediaries' websites turned out to be similar in structure, including core information such as 'who we are' (history and vision), 'what we do' (services/activities) and 'why choose us?' (perceived value). This information not only gave us a more comprehensive view of the companies but also helped us to better understand some of the signals that intermediaries send to potential customers. We therefore utilised information retrieved from secondary data throughout the research process for the tasks of data analysis, triangulation and complementing the primary data.

\section{Data analysis}

The data was analysed using an interpretive thematic analysis approach (Miles and Huberman, 1994). First, we conducted a within-respondent analysis, primarily using interview data supported by secondary data. Informed by extant literature and guided by our research question, we paid specific attention to intermediaries' proactive role in sharing information within the triad (buyers, sellers and intermediaries) and providing signals of their intrinsic value in operations. The interview transcripts were carefully examined, key words were highlighted in the text and labels were added. Sentences that were considered supportive to key words were also highlighted, and some of them were later selected as the 'power quotes' (Pratt, 2008) used in this paper. The highlighting also helped us keep the coding process as transparent and traceable as possible. Next, we categorised the identified key words and created a list of codes with explanatory notes for each respondent. Then we proceeded to a cross-respondent analysis. All the codes and quotes derived from the within-respondent analysis were compared and categorised across all respondents to identify themes. 
We found the first-order codes inductively in the data. When abstracting and grouping these into higher-order themes (Cresswell, 2013), we sharpened the themes by connecting them with existing literature on intermediaries' activities, following the logic of abduction (Dubois and Gadde, 2002). Through this process, four theoretical dimensions emerged: matchmaking, transparency, physical distance mediation and cultural distance mediation. After multiple cycles of data analysis, it became apparent that for middlemen operating in the contemporary context of sourcing from China, informational aspects come to the fore as a key competitive advantage. We visualise the data structure in Figure 2.

Insert Figure 2 about here

In line with qualitative research, our research process shows many turns and we allowed for flexibilities. We started by only analysing Nordic intermediaries, but realised that for a better understanding of the role of intermediaries between Nordic buyers and Chinese suppliers, we had to extend the analysis to cover Chinese intermediaries as well. Our intention was not to conduct a comparative study of these actors but rather to gain a comprehensive understanding of the intermediation taking place in this cross-cultural setting. Secondly, in the course of the study, our focus changed from looking at the basic activities of intermediaries to more specifically investigating their informational role in intermediation, and this brought us to the issue of signalling as well. In order to cover potential changes caused by recent developments in global business, we returned to some respondents for check-ups in 2021. Finally, we see that while we started with a descriptive approach to contemporary intermediation in global sourcing, we moved in a more analytic direction, and as a result, we can now provide insights that build on rich empirical data and its interplay with existing research. 


\section{Results}

We rely on the concept of information asymmetry to understand the triadic setting wherein intermediaries operate between buyers and suppliers in sourcing from China. We first explicate this setting by discussing how the pre-contractual and post-contractual situation is experienced by the involved actors. We mainly refer to our interviews with buyers and the scholarly views on why intermediaries are needed. Next, we focus on the informational activities of intermediaries, mainly through their own accounts, including both Nordic and Chinese intermediaries. We identified four distinct informational roles that the intermediaries fulfil in the triads. The identification of these roles leads us to coin the term modern mediators to reflect their proactive and extensive roles in contemporary global sourcing. Finally, the results related to the outlook of the intermediaries are discussed. Table IV presents the pre-contractual and post-contractual problems, and the corresponding intermediaries' informational activities with illustrative quotes from the respondents.

Insert Table IV about here

\section{Setting the stage: The need for involving an intermediary}

The information asymmetry existing between Chinese suppliers and Nordic buyers, compounded by geographical and cultural distance, causes both pre-contractual and post-contractual problems. In the pre-contractual screening phase (the first column in Table IV), an informational problem occurs when Nordic buyers lack information about Chinese suppliers' compatibility and true qualifications. On the one hand, because of limited knowledge about the supplier's production capacity and how compatible it is with the needs of the buyer, a small buyer may become downprioritised by a large supplier in term of deliveries and commitment to a quality standard: 
The agent has to know the customer well - what kind of quantities, quality and products the customer needs - and to find suitable factories for those requirements. So, in our case, it's not clever to recommend to us factories that work with H\&M. It's not very interesting for them [large Chinese suppliers] to work with a very small client. And also, perhaps because of that, we had quality issues. (B2[FI])

On the other hand, the physical and cultural separation erodes the basis for trust, raising the informational costs involved in searching for and selecting suitable suppliers. The lack of information about potential suppliers' true qualifications increases buyers' uncertainty and the need to know the suppliers better and meet them face to face before initiating relationships:

If you start something new, then it is much more important to go and see how the process works, to give your feedback face to face and to know the partners face to face as well. That's very important. (B2[FI])

In the post-contractual relationship, effective supplier monitoring becomes challenging when the buyers lack information about the daily operations taking place in China. The geographical separation makes it problematic for the buyers to conduct, for instance, quality inspections:

We are in Sweden, and the factories are in China; it's a long way. It's not very convenient for us to travel there very often. So, we also get quality control from M4(FI). (B1 [SE])

Furthermore, cultural differences impose barriers to smooth information flow. Lacking information about the differences in cultural behaviour and thinking patterns may lead to ineffective communication, resulting in low-quality products and poor delivery performance. Sometimes, although the cultural differences have been noted, the desired outcome fails to be realised because of the unsuccessful conveying of each other's intentions and objectives, as explained by a Finnish buyer and a Chinese supplier below: 
Earlier we had these problems of the fabric quality being poor even though they [the Chinese supplier] have noticed it and they have rejected it and reordered the fabric, which is good - which is what they are supposed to do - we haven't had any information about that happening. I know it can sometimes be difficult to inform customers about bad experiences or mistakes in Chinese culture, but from our point of view - whether it's good news or bad news - we just need to know the news so that we know what's happening. (B2[FI])

When a problem occurs, we usually handle it according to two different situations. First, if there is a long time before the delivery deadline, we will try to solve the problem on our own. Then, if the problem happens right before the delivery, we will inform the customer immediately. After all, the customer wants solutions, not questions. ( $\mathrm{S} 1[\mathrm{CN}])$

\section{The four informational roles of the intermediary}

The role of modern mediators was identified as being composed of the following four constructs that reflect their value in reducing information asymmetry and improving information flow between Chinese suppliers and Nordic buyers: matchmaking, transparency, physical distance mediation and cultural distance mediation (these are also illustrated in the last two columns of Table IV and in the data structure in Figure 2).

\section{Matchmaking}

In the pre-contractual screening phase, foreign buyers with limited experience of sourcing from China have difficulties in finding desirable suppliers and verifying the compatibility of suppliers' characteristics and goals with their own. Therefore, to reduce this information asymmetry, intermediaries play a critical role in matching the buyers with the most compatible suppliers. This role of matchmaker consists of two main functions: searching for and selecting a supplier, and supply-demand consolidation. 
- Searching for and selecting a supplier

As the Chinese supply market becomes more accessible to foreign buyers through the internet and international trade fairs, intermediaries' traditional supplier search function has gradually lost its importance. In order to remain valuable, intermediaries have deployed resources to develop their ability to select the most compatible suppliers, which requires a solid understanding of both the supplier's qualification and production capacity, and the customer's requirements. Suppliers should be, for example, of a suitable size in comparison with the buyers: neither too big nor too small. In this way, the supplier can reach the required production capacity and product variety, and the buyer is interesting enough for the supplier. A Finnish buyer commented:

Now we are a good customer for the supplier - our order is big enough for them to do business. Now it's more interesting for the suppliers to keep us happy. And when we have some claims, they're easily handled. (B2[FI])

In addition to being close to and familiar with the qualified suppliers, Chinese intermediaries have a significant advantage in offering financing. This is especially evident for products that require high investment and a long payment period. With their full or partial state ownership, Chinese intermediaries have high credit limits and access to sufficient funds. This financing function ensures that the selected suppliers are capable of delivering production and fulfilling contractual obligations. Thus, state ownership or affiliation with the government form a signal that Chinese intermediaries may send in order to convey their ability to not only provide financial support but to also select the most qualified suppliers. A Chinese intermediary explained the situation as follows:

Most factories in China are small ones, and they lack the qualifications and capacity the customers need. Plus, these factories need the full payment before delivery, but the customers can only pay a 
maximum of a $30 \%$ deposit. We, on the other hand - with our qualifications and capital - can select suitable suppliers and finance their production. (M13[CN])

\section{- Supply-demand consolidation}

An important part of the matchmaking activity is supply-demand consolidation. Chinese intermediaries emphasise the product variety they can provide by collaborating with a number of different factories:

One factory can only produce one or two types of fabric because they don't have that many machines. The customers can buy a variety of products from our company because we work with many different factories. That is our biggest advantage. (M10[CN])

Nordic intermediaries, in turn, focus more on combining orders of different sizes from various buyers to achieve economies of scale. In most cases, this means that the supplier will even give priority to a small order because of the long-term supplier-intermediary relationship, and the intermediary deserves attention with its combined order volume:

The more business volume you bring to a supplier as a single entity, the more attention you will get and the the suppliers will more readily accept small orders. Even large companies sometimes buy a certain product in small quantities. (M1 [SE])

The supply-demand consolidation function is enabled by intermediaries' vast supply network, high product variety and broad customer base. A related signal is the demonstration of the number, and possibly the names, of suppliers and customers with whom the intermediary collaborates. M1(SE), for example, presents all its existing customers (via company logos and links to the company websites) on its website. 
Thus, the matchmaking ability of the intermediaries, including their superior understanding of both parties' expectations and resources, can be regarded as a unique resource that reduces the information asymmetry between the buyer and the supplier.

\section{Transparency}

Another informational role adopted by intermediaries during the pre-contractual supplier selection phase relates to transparency in supply chains. First, and somewhat surprisingly, intermediaries allow for buyer-supplier interaction, and secondly, to an increasing extent they offer services of social compliance management.

\section{- Buyer-supplier interaction}

Connecting buyers and suppliers directly is a move of significance as it transforms two dyadic relationships into an interconnected triad. In this kind of triadic relationship, intermediaries do not typically conceal information of suppliers or product prices from their customers. They signal their honesty by offering open books and cost visibility for buyers. The intermediated buyer-supplier interaction typically includes detailed discussions regarding product specifications, quality inspection, factory and showroom visits, and informal dinners.

Through the internet and e-commerce, intermediaries' potential benefits from disclosing supplier information have been rapidly reduced. However, uncertainty caused by lacking information about foreign partners' true qualifications persists. From the buyer's perspective, meeting suppliers face to face is important in order to clarify details and to build trust, especially when new projects are launched. From the intermediaries' perspective, transparency is a good marketing tool that counters the potential negative image associated with intermediary opportunism: 
An important part of our business model is to be completely transparent with all information regarding, for instance, the names and information of the suppliers we use, the prices from the suppliers and our commission. When the customers understand that we are $100 \%$ transparent, $100 \%$ honest and open in everything we do, I gain a lot of customers. (M1[SE])

Additionally, we found that whether or not an intermediary takes title to the traded goods affects the level of transparency to some extent. Intermediaries that take title are usually unwilling to disclose supplier information to the buyers as their profit is obtained from the difference between the buying and selling price, which increases their incentive to avoid transparency. However, titletaking intermediaries can reduce the buyers' monitoring costs by bearing the financial risks for them. Thus, intermediaries' ability to take title sends ambiguous messages and cannot be considered as an effective signal.

\section{- $\quad$ Supplier monitoring}

The need for constant supplier monitoring became evident in our study. Moreover, buyers express increasing needs for knowledge of the upstream actors in supply chains. The need for buyers to know the suppliers' true qualifications is amplified by the increasing concerns for corporate social responsibility. Presenting a more transparent supply chain is not only an act that signals the trustworthiness of the suppliers but also a requirement from the buyers. The evaluation of suppliers in social compliance issues - such as the working environment, child labour and environmental conditions - has become a new service that intermediaries provide, and it is especially evident with intermediaries dealing with branded consumer products which require premium quality and ethical production processes. As the demand for social compliance management increases, intermediaries make it a service separate from supplier monitoring regarding the production process and assign specialised resources in order to provide this service: 
Nowadays many customers are interested in social compliance. We know the details and processes and challenges very well. If it's needed, we can go to the factories and check. It seems that this is becoming more and more important. (M4[FI])

Social compliance management is, however, not a typical service offered by Chinese intermediaries. Despite the emphasis on the importance of this issue by Nordic intermediaries and buyers, the Chinese intermediaries in our study claim that they do not see any change in customers' requirements regarding environmental or social matters. For example, M10(CN), which works with one of the largest apparel retailers in the world, said:

I don't feel any pressure from Western customers about environmental or social requirements. They just place the order, and then we quote a price. There is, however, increasing environmental pressure from the Chinese government, and that increases our costs. (M10[CN])

In summation, increasing the level of transparency between suppliers and buyers essentially decreases buyers' uncertainty concerning suppliers' trustworthiness and the quality of deliveries. Through such signals as cost visibility, buyer-supplier interaction and social compliance management, intermediaries show current or potential buyers that they, as well as their suppliers, are honest and reliable.

\section{Physical distance mediation}

Controlling quality and securing delivery represent two core activities of the studied intermediaries. Both of these activities have been mentioned in the previous literature (e.g. Vedel and Ellegaard, 2013; Sartor et al., 2014), but there is little discussion on what intermediaries do to achieve better quality and on-time delivery, and what kind of resources they utilise to achieve these things. As the geographical distance between China and Europe magnifies the problem of information asymmetry between suppliers and buyers, it is resource demanding and costly for 
Nordic buyers to monitor the production processes at Chinese suppliers' factories. To ensure sufficient quality and prompt delivery, intermediaries reduce information asymmetry by mediating the physical distance with concrete practices. One observable signal that intermediaries send is that they have local presence and local employees in both China and the West.

\section{- Proximity to suppliers}

Intermediaries' Chinese employees located near the suppliers are able to conduct frequent quality checks and production process follow-ups, and can negotiate in disputes. Some Chinese intermediaries have also invested in building their own quality testing laboratories close to the suppliers. According to our respondents, information asymmetry is reduced by having a reliable contact person in China who can update the buyers about the product quality, production process and delivery status:

At this moment, we have two persons in China doing the quality inspection full time. It's important for the customers that there is some contact. They don't have time to travel to China very often and check everything. They can easily see about all the details on one page. (M4[FI])

- Proximity to buyers

The informational costs caused by physical separation are further reduced by having offices in the customers' proximity. Our respondents confirmed this by emphasising how easy it is to contact someone in the same country. In addition, the customers tend to feel more comfortable to discuss business matters in their native language, and they tend to believe that a company from their home country is more trustworthy than a foreign one. Intermediaries with employees that share a common language and cultural background with the customers possess preconceived trust and thus can foster an effective information flow between suppliers and buyers: 
It's so much easier for the customer to contact me. They can give me a call when they are in the car, no need to think about what the time is in China and whether the Chinese employees are still working. They know my address and where I live. Plus I speak the same language that they do. (M2[FI])

This kind of organisational structure, with the combination of both supplier and buyer proximity, bridges Nordic buyers' information gap in regard to Chinese suppliers' day-to-day tasks.

\section{Cultural distance mediation}

The fourth role that intermediaries play to minimise problems caused by information asymmetry is that of cultural distance mediator. Our findings show that barriers to smooth information flow are often related to culture. Issues such as poor quality and delays in delivery are in fact often caused by misinterpretations in communication rather than opportunism. Intermediaries, especially Western intermediaries, play a crucial role in bridging trust and guiding Chinese suppliers or their own quality control employees in improving their understanding of the buyers' objectives.

\section{- Trust building}

Intermediaries facilitate the trust building process by having a long-term view and close personal relationships with their buyers and suppliers. Intermediaries typically signal their long-term orientation by explicitly showing the age of the relationship:

As a sourcing agent, having a long-term business relationship is our business model and competitive advantage. Our relationships with some suppliers have lasted over 20 years. (M2[FI]) 
The business relationship is maintained and deepened by arranging regular mutual visits and various informal dinners. For Nordic intermediaries, it is important to 'sit and drink' with their Chinese suppliers, as was noted:

Over the years, we become more familiar with the Chinese suppliers as the trusted suppliers have worked with us for nearly a decade. The longer you do business, the longer you have to 'sit and drink' and the better you know them. (M3[FI])

Trust has also been built through cultural affinity by employing nationals of both the source and buying countries. M1(SE), for example, signals this cultural advantage by emphasising on its website that it is 'a Chinese company with Swedish management'. For Chinese suppliers, trust can be created by simply hiring a Nordic intermediary as it is the connecting bond and possess preconceived trust from the Nordic buyers. This was emphasised by the Chinese supplier in our study:

When sourcing from China, our Finnish customers' trust is built on the trust of M1(FI). (S1[CN])

\section{- Guidance}

Finally, we saw that for smooth business interaction, detailed guidance by the intermediary was needed. Several respondents mentioned the issue of the parties looking at issues with 'different eyes', meaning that Chinese suppliers tend to have different perceptions of, for example, product quality than Nordic buyers:

We teach them how to have good quality control, how to make an on-time delivery ... They get trained all the time by dealing with Scandinavian or other European customers. I teach them how to look at things with 'European eyes'. (M1[SE])

Furthermore, the 'silence issue' - situations where the Chinese suppliers are unwilling to disclose 'bad news' about important matters, such as delays in delivery to the buyers, in good time - can 
severely hamper the information flow. This gives some Nordic buyers the impression that the Chinese suppliers 'don't say the whole truth'. One respondent described this:

The Chinese sometimes keep quiet because they are afraid of informing you of bad news. They inform you when the problem has been solved. They don't reply to you if they think they don't have a good answer. (M5[FI])

On the other hand, the Chinese supplier S1(CN) believes that customers are solution orientated, and therefore, the Chinese suppliers always try to solve problems first by themselves. However, an evident contradiction appears here: while the Chinese supplier trusts that they meet the customers' thinking patterns and culture, all our interviewed Nordic companies considered such a 'silence issue' to illustrate a Chinese way of thinking.

In this kind of situation, problems arise when Chinese suppliers are not fully aware of Nordic buyers' expectations, and the buyers, on the other hand, do not see that the suppliers' interpretation and perception of the objectives are different from their own. With the help and guidance of the intermediaries, the buyers become aware of the suppliers' interpretations and the suppliers are able to fully comprehend the buyers' expectations. Thus, the goals of the buyers and suppliers are aligned, resulting in better product quality and timely delivery. Such an ability for guidance requires long-term mutual learning and investment, reflecting the intermediary's control capability and commitment to the relationship. The intermediaries' guidance ability is especially required when dealing with complex products, such as designed clothing or customised industrial components, which require the suppliers' full comprehension of the product specifications. Therefore, specialisation in more differentiated goods can be regarded as an unambiguous signal that intermediaries send to indicate their value in guiding and solving informational problems. 


\section{The future outlook}

While we do not aim for a longitudinal study, our data alludes to the standing position of intermediaries in sourcing from China. Our respondents were not concerned about their position, despite COVID-19 and the many triggers of deglobalisation. As to the question of whether the pandemic or backshoring decisions have had impacts, they note the following:

As a whole, we have gained far more customers and business than we have lost thanks to the pandemic. I get contacted almost every day by potential customers from all over the world that need help from someone in China that they can trust as a third-party sourcing agent. (M1[SE])

There is pressure from the idea that supply chains and networks should be wider and more resilient to this kind of change. But we are in the services business; for us it is quite moderate to shift from product to product. (M4[FI])

The Chinese industry expert E1(CN), emphasised (again) the power of offering a wide range of services:

For intermediaries that simply make a profit out of the price difference, their chance of survival is greatly reduced because factories can now easily have access to end customers. But for intermediaries that can develop specialised services, there is still a lot of space to grow. (E1[CN])

\section{Discussion}

In this study, we have focused on intermediaries' role in decreasing the information asymmetry between suppliers and buyers, with the intention of investigating their means for ensuring a lasting role in contemporary value chains. We bring to the fore the typical problems met in Chinese sourcing when it comes to linking buyers with suitable suppliers, as well as the respective intermediary activities (that is, the solutions to overcome these challenges). The activities were 
organised according to the phases of intermediation (pre-contract and post-contract intermediation), in order to show the particularities of operations when the parties have potential versus actual mutual business relations. Furthermore, we found that intermediaries' activities revolved around the issues of information sharing and signalling. Here, we discuss these different intermediary activities in the light of previous studies.

The extant literature emphasises the critical role that intermediaries play in searching for new suppliers due to their superior information of the foreign markets (Popp, 2000; Vedel and Ellegaard, 2013). However, information asymmetries across countries have been reduced as a result of the development of the internet, the increasing integration of the world economy (Wang et al., 2018) and culture's all-dimensional learning (Fang et al., 2017). Therefore, it is no longer sustainable for intermediaries to 'have some contacts in China' and keep all the related information secret. Our data shows that in the pre-contractual phase, despite the decreasing information asymmetry, Nordic buyers still suffer from a lack of information about suppliers' compatibility and true qualifications. Unlike portraying intermediaries as information monopolists (Perry, 1990), we found that the analysed intermediaries add value by reducing information asymmetry through the activities of matchmaking and increasing transparency. This finding adds to the discussion of information costs, which suggests that intermediaries economise on information costs and integrate markets over space and time (Casson, 1997; Popp, 2000).

Identification of the changes in the relationship between intermediaries and information costs, as well as identification of their proactive approaches, leads us to call these intermediaries modern mediators. These intermediaries are not concerned about being replaced by allowing transparency. Indeed, their position as value-creating actors relies on their ability to improve the quality of information exchanged rather than capture monopoly rents. This finding adds to the discussion of 
the 'trader's dilemma' (Ellis, 2005) by suggesting conditions under which bypassing intermediaries may not be a wise option.

In post-contractual relationships, we found that the problems of poor delivery performance and low-quality products arise when Nordic buyers lack information about suppliers' daily operations and the suppliers' perception of the objectives. Intermediaries reduce these two types of information asymmetry by mediating the physical and cultural distance between Chinese suppliers and Nordic buyers. These results suggest that intermediaries' proximity to both the buyers and suppliers not only bridges geographical separations between buyers and suppliers but also strengthens the basis for trust. This finding aligns with the evidence that intermediaries' geographical focus and configuration reflect the characteristics (e.g. the legal and cultural aspects) of the countries of both the headquarters and the sourcing area (Sartor et al., 2014). It is worth noting that we approached the respondents with a relatively general view of psychic distance (Johanson and Vahlne, 1977), which includes different barriers for information flows. The respondents themselves, however, discussed geographic/physical and cultural issues; thus our model contained these two particular aspects of distance.

The findings highlight the influence of institutional contexts and the nationality of the firm on intermediaries' informational roles and resources for fulfilling them. The Chinese intermediaries in this study are significantly larger than the Nordic intermediaries and tend to be either partially or fully owned by the government, which grants them a competitive edge in providing financial services to support matchmaking. This capital advantage is also shown by the fact that compared with the Nordic intermediaries, more of the Chinese intermediaries take ownership of the goods traded. This may potentially explain the overall greater effort made by Nordic intermediaries to improve the information flow rather than the material flow. In terms of institutional distance, the 
Chinese intermediaries seem to have a firmer grasp of the supply networks in China and have stronger relational ties with local government and shipping companies. The Nordic intermediaries, in turn, appear more trustworthy to Nordic buyers and understand the quality requirements of the buyers better. Additionally, while social compliance management is becoming increasingly important for the Nordic intermediaries, it has not yet been seen as relevant by the Chinese intermediaries. In this respect, we would expect changes to take place in the future.

Earlier studies pinpoint that intermediaries play a critical role in bridging the cultural distance between suppliers and buyers in undeveloped or unfamiliar supply markets, but less so in established global supply markets, such as China, due to the learning effects (Fang and Faure, 2010; Vedel and Ellegaard, 2013). Conversely, our analysis shows that despite the dissemination of cultural awareness and knowledge of business operations in China, cultural distance persists when the buyers lack information about suppliers' perception of the sourcing objectives. We found that poor sourcing outcomes are often caused by suppliers' misinterpretation of buyers' objectives, rather than opportunism, which is the conventional assumption (Williamson, 1996). This finding is in line with the honest incompetence and bounded reliability views, which suggest that economic actors are intendedly reliable, but only boundedly so (Kauppi and van Raaij, 2015). In this light, intermediaries' activities concerning trust building and guidance can effectively reduce this type of information asymmetry between suppliers and buyers, especially in a cross-cultural context.

Furthermore, this study advances our understanding of intermediaries' signalling activities. Signalling theory is relevant for addressing the information asymmetry characterising cross-border exchanges (Reuer and Ragozzino, 2014) but has not yet been applied to understanding intermediaries' signalling behaviour in resolving informational conflicts between geographically dispersed buyers and suppliers. Our findings show that intermediaries are in a position to signal 
their unobservable characteristics and value in offering services in a triadic relationship in both pre-contractual and post-contractual phases. However, we were only able to identify a limited number of signals used by the intermediaries. It seems that the intermediaries have difficulty in creating visible signals with which to convey information about their intangible informational functions, such as trust building and guidance. In addition, our results did not confirm the importance of such signals as taking title and specialisation in commodity products, which were suggested by Peng and York (2001). When the intermediary takes title, it tends to keep the intermediated buyer-supplier relationship less transparent and thus sends an ambiguous signal to the customers about their honesty and trustworthiness. Regarding product specialisation, we found that intermediaries become more valuable when handling complex products with customisation which require dedicated guidance ability from intermediaries.

Previous studies have revealed several of the discussed intermediary activities (as shown in Appendices 1 and 2), but our analysis links them to the informational problems that buyers face in the changing context of global sourcing and in this way provides a new perspective on intermediaries' activities in ensuring their position in global value chains.

\section{Conclusions}

\section{Implications for theoretical development}

This research makes several theoretical contributions. To begin with, the study contributes to the scientific debate on the usefulness of intermediaries by underlining intermediaries' informational advantage, which provides an explanation for the survival of intermediaries in a rapidly changing business context. We thus contrast studies that see intermediary services to represent only the initial stage of international business development (Monczka and Trent, 1991; Nassimbeni and 
Sartor, 2007), and add to the discussions of repeating (Cole and Aitman, 2020) and permanent (Popp, 2000; Vedel an Ellegaard, 2013) roles of intermediaries. The development of the internet combined with the continuous internationalisation of firms has brought buyers and manufacturers closer together with significantly reduced information asymmetry (Ellis, 2001; Peng and York, 2001). Our results show, however, that informational problems continue to exist due to geographical and cultural separation. Through the lens of information asymmetry, we identified intermediaries' informational roles and linked them with pre-contractual and post-contractual problems between geographically and culturally dispersed suppliers and buyers. Our study does not emphasise the adversarial use of information but rather challenges the widespread belief that intermediaries are information monopolists who add costs but not value (Perry, 1990). We provide empirical evidence that intermediaries survive in today's increasingly precarious world because they have successfully developed and utilised their informational roles in order to improve transparency in the information flow between the two parties they connect.

Moreover, the study provides a more nuanced understanding of intermediaries' informational roles by taking a triadic perspective. Research so far has focused on the exporter-intermediary dyadic relationship, assuming that the intermediary is an opportunistic, self-interested seeker (Peng and York, 2001). Then, formal control-based mechanisms are needed to curb the intermediaries' opportunistic behaviour in the principal-agent dyad (Karunaratna and Johnson, 1997). By studying the relational dynamics in a buyer-intermediary-supplier triadic setting, we found that intermediaries are imperative in facilitating the information flow and, consequently, coordination between buyers and suppliers that are otherwise disconnected. The findings provide further support for the notion that informal relational governance mechanisms, such as norm-based bidirectional information exchange and trust building, are likely to achieve better channel performance and 
higher goal congruence than control-based governance mechanisms (Karunaratna and Johnson, 1997).

Furthermore, this research is, to our knowledge, the first to examine intermediaries' signalling strategies in a cross-border buyer-intermediary-supplier triad. Earlier studies on exporterintermediary dyadic relationships suggest that an intermediary may aim at signalling to the exporter that it is the type of intermediary the exporter is seeking (Peng and York, 2001). Moreover, signalling theory has mainly been applied to examine the ex ante exchange hazard of adverse selection (Bergen et al., 1992; Reuer and Ragozzino, 2014). We extend these studies by identifying signalling activities that intermediaries apply to indicate their capabilities in relation to reducing asymmetric information between buyers and suppliers in both pre-contractual and postcontractual stages. However, given that we found relatively few signalling activities and did not initially focus on this aspect in the study, there are ample possibilities for further development of this particular notion, both empirically and conceptually.

Finally, this study contributes to research on intermediation strategies by throwing some light on the similarities and differences between Chinese and Nordic (Western) intermediaries, emphasising the importance of institutional contexts in affecting intermediaries' informational roles. This extends current studies, which have primarily focused on Western intermediaries in sourcing from China (Salmi, 2006; Jia et al., 2014b). All four informational roles were identified in both groups of intermediaries, but there were differences in their importance and how they were performed that resulted from the influence of the institutional specifics of the intermediary's country. Such findings pave the way for future studies with a comparative setting in order to dig deeper into the features of intermediaries in different national and international settings. 


\section{Implications for managerial practices}

This study provides important managerial implications for utilising intermediation strategies in global sourcing and international trade through the analysis of potential value-generation opportunities for intermediaries. Direct sourcing and intermediated sourcing are the two basic global sourcing strategies for supply chain managers to consider (Nassimbeni and Sartor, 2007). While sourcing directly and cutting out the middleman may seem appealing, our study shows that sourcing through intermediaries can bring a wide range of extra value to their customers. Sourcing managers need to carefully consider their sourcing objectives and resources when deciding on the sourcing strategy. Potential problems caused by information asymmetry between suppliers and buyers may emerge when sourcing from culturally and geographically distant countries. Companies without sufficient resources for solving such problems are urged to reach for trustworthy partners with expertise in bridging information gaps. In this case, an intermediary becomes a viable option.

The findings from this research enable intermediary practitioners to craft better strategies and generate value for their customers through the four informational roles and related signals. Intermediaries need to be proactive, adopt new behaviour and pay special attention to informational activities. Signalling about their activities and abilities forms an important tool for modern mediators to address contemporary dynamics in international business.

Intermediaries' client firms (e.g. buyers and suppliers) may also make more informed channel choices by looking for such information-related activities and signals when searching for and selecting qualified intermediaries. As many of intermediaries' value-adding characteristics are not directly visible, we encourage intermediaries to create and present signals that are easily observable by the customers. For example, an intermediary with a headquarters located in the West 
and employees in the sourcing destination sends an effective signal of being able to transfer information efficiently between buyers and suppliers.

\section{Limitations and implications for future research}

Our study shows the activities of both Nordic and Chinese intermediaries in the past few years. However, this does not allow for a more extensive understanding of changes in their role over time. Because of the fundamental changes in the global business setting, with several triggers for deglobalisation and the decoupling of value chains (Witt et al., 2021; Witt, 2019b; Petricevic and Teece, 2019), the role of intermediators in cross-border sourcing is bound to become even more topical, both academically and managerially. Longitudinal studies using survey or case study methods are called for to clarify this issue. Future research needs to acknowledge the dynamic nature of intermediation as intermediaries and their activities are evolving in order to address new demands, as shown here. In particular, we urge for analysis of the dynamics related to formal and informal relationship governance mechanisms in order to better understand how the (buyerintermediary-seller) triads evolve and can be managed. Moreover, despite our efforts, we were not able to reach connected respondents along longer value chains. Future studies that include more voices from intermediaries' suppliers and buyers (that is, the members of different supply chain tiers) may generate new insights. This study is novel in its application of the theoretical lens of signalling theory in the context of a cross-border buyer-intermediary-supplier triad, but due to the nature of the data collected, our findings in this respect are limited. Future research investigating how intermediaries develop and utilise their signalling capabilities in international triadic relationships may yield fruitful results. As both signalling theory and agency theory address problems of information asymmetry in markets, an examination of intermediaries' signalling behaviour in an agency triad would be a promising start. Intermediation research would benefit 
from cross-fertilisation between the two research streams, and moreover, international business studies offer valuable contextualisation for such investigations. Finally, the empirical data of this study focuses on Chinese and Nordic firms. Finnish and Swedish intermediaries operate in relatively similar institutional settings and, like other Nordic countries, represent small open economies. In many ways they are valid representatives of European and Western companies more generally as well. However, we acknowledge that the results may not be directly applicable to other national contexts due to the institutional, cultural and resource-based differences of countries. We hope that this research will inspire studies in other contexts in order to extend our understanding of intermediaries' current and future role in global sourcing as it may indeed be much more proactive and critical than assumed by the existing literature. 


\section{Appendix 1}

Insert Table AI about here

\section{Appendix 2}

Insert Table AII about here

\section{Appendix 3}

Insert Table AIII about here

\section{References}

Akerlof, G.A. 1970. The market for "lemons": Quality uncertainty and the market mechanism. Journal of Economics, 84(3): 488-500.

Ancarani, A., Di Mauro, C., Virtanen, Y., \& You, W. 2020. From China to the West: why manufacturing locates in developed countries. International Journal of Production Research, 59(5): 1-15.

Bergen, M., Dutta, S., \& Walker, O. 1992. Agency relationships in marketing: A review of the implications and applications of agency and related theories. Journal of Marketing, 56: 1-24.

Casson, M. 1997. Institutional economics and business history: a way forward. Business History, 39(4): 151-171.

Cole, R., \& Aitken, J. 2020. The role of intermediaries in establishing a sustainable supply chain. Journal of Purchasing and Supply Management, 26(2).

Cresswell, J.W. 2013. Qualitative Inquiry Design: Choosing Among Five Approaches. Thousand Oaks, CA: Sage. 
Delios, A., Perchthold, G. \& Capri, A. 2021. Cohesion, COVID-19 and contemporary challenges to globalization. Journal of World Business, 56(3).

Dubois, A., \& Gadde, L.-E. 2002. Systematic Combining: An Abductive Approach to Case Research. Journal of Business Research, 55: 553-560.

Ellis, P. 2001. Adaptive strategies of trading companies. International Business Review, 10(2): 235259.

Ellis, P. 2003. Are international trade intermediaries catalysts in economic development? A new research agenda. Journal of International Marketing, 11(1): 73-96.

Ellis, P. D. 2005. The trader's dilemma: the adverse consequences of superior performance in mediated exchange. International Business Review, 14(4): 375-396.

Ellis, P. D. 2010. International trade intermediaries and the transfer of marketing knowledge in transition economies. International Business Review, 19: 16-33.

Ellram, L. 1996. The use of the case study method in logistics research. Journal of Business Logistics, 17(2): 93-138.

Eriksson, P., \& Kovalainen, A. 2008. Qualitative methods in business research. London: Sage.

Fang, T., \& Faure, G.O. 2010. Chinese communication characteristics: A Yin Yang perspective. International Journal of Intercultural Relations, 35:320-333.

Fang, T., Gunterberg, C., \& Larsson, E. 2010. Sourcing in an Increasingly Expensive China: Four Swedish Cases. Journal of Business Ethics, 97: 119-138.

Fang, T., Tung, R.L., Berg, L., \& Nematshahi, N. 2017. Parachuting internationalization: a study of four Scandinavian firms entering China. Cross Cultural \& Strategic Management, 24(4): 554589.

Fratocchi, L., Ancarani, A., Barbieri, P., DiMauro, C., Nassimbeni, G., Sartor, M., Vignoli, M., \& Zanoni, A. 2016. Motivations of Manufacturing Reshoring: An Interpretative Framework. International Journal of Physical Distribution and Logistics Management, 46(2): 98-127.

Fung, P.K.O., \& Chen, I.S.N. 2010. Human capital for supply chain management capabilities: a study of international trade intermediaries. International Journal of Logistics: Research and Applications, 13(1): 1-12.

Gereffi, G. 2020. What Does the COVID-19 Pandemic Teach us About Global Value Chains? The Case of Medical Supplies. Journal of International Business Policy, 3: 287-301.

Giannakis, M., Doran, D., \& Chen, S. 2012. The Chinese paradigm of global supplier relationships: Social control, formal interactions and the mediating role of culture. Industrial Marketing Management, 41 (5): 831-840.

Giunipero, L., \& Monczka, R. M. 1990. Organisational approaches to managing international sourcing. International Journal of Physical Distribution and Logistics Management, 20:3-12.

Glaser, B.G., \& Strauss, A.L. 1967. The Discovery of Grounded Theory: Strategies for Qualitative Research. Chicago: Aldine.

Havila, V., Johanson, J., \& Thilenius, P. 2004. International business-relationship triads. International Marketing Review, 21: 172-186. 
Huo, B., Gu, M., \& Jiang, B. 2018. China-related POM research: Literature review and suggestions for future research. International Journal of Production Economics, 203: 134-153.

Jensen, M., \& Meckling, W. 1976. Theory of the firm: Managerial behavior, agency costs and ownership structure. Journal of Financial Economics, 3: 303-431.

Jia, F., Lamming, R., Sartor, M., G., \& Nassimbeni, G. 2014a. Global purchasing strategy and International Purchasing Offices: Evidence from case studies. International Journal of Production Economics, 154: 284-298.

Jia, F., Lamming, R., Sartor, M., Orzes, G., \& Nassimbeni, G. 2014b. International purchasing offices in China: A dynamic evolution model. International Business Review, 23(3): 580-593.

Johanson, J., \& Vahlne, J. 2009. The Uppsala internationalization process model revisited: From liability of foreignness to liability of outsidership. Journal of International Business Studies, 40(9): 1411-1431.

Johanson, J., Vahlne, J.-E. 1977. The internationalization process of the firm - A model of knowledge development and increasing foreign market commitments. Journal of International Business Studies, 8(1): 23-32.

Karunaratna, A.R., \& Johnson, L.W. 1997. Initiating and Maintaining Export Channel Intermediary Relationships. Journal of International Marketing, 5(2): 11-32.

Kauppi, K. \& van Raaij. E.M. 2015. Opportunism and Honest Incompetence-Seeking Explanations for Noncompliance in Public Procurement. Journal of Public Administration Research and Theory, 25(3): 953-979.

Larsen, M. M., Manning, S., \& Pedersen, T. 2013. Uncovering the Hidden Costs of Offshoring: The Interplay of Complexity, Organizational Design, and Experience. Strategic Management Journal, 34 (5): 533-552.

Lassar, W., \& Kerr, J. 1996. Strategy and control in supplier-distributor relationships: An agency perspective. Strategic Management Journal, 17: 613-32.

Li, L. 2003. Joint effects of factors affecting exchanges between exporters and their foreign intermediaries: an exploratory study. Journal of Business \& Industrial Marketing, 18(2): 162178.

Mavlanova, T., Benbunan-Fich, R., \& Koufaris, M. 2012. Signaling theory and information asymmetry in online commerce. Information \& Management, 49: 240-247.

Miles, M.B., \& Huberman, A.M. 1994. Qualitative Data Analysis. (2nd ed.). Thousand Oaks, CA: Sage Publications.

Monczka, R.M., \& Trent, R.J. 1991. Global sourcing: a development approach. International Journal of Purchasing and Materials Management, 27(2): 2-8.

Nassimbeni, G., \& Sartor, M. 2007. Sourcing in China: a typology. International Journal of Production Economics, 107: 333-349.

Patton, M. Q. 2002. Qualitative research \& evaluation methods. London: Sage Publications.

Peng, M.W., \& York, A.S. 2001. Behind Intermediary Performance in Export Trade: Transactions, Agents, and Resources. Journal of International Business Studies, 32(2): 327-346. 
Peng, M.W., Hill, C., \& Wang, D. 2000. Schumpeterian Dynamics Versus Williamsonian Considerations: A Test of Export Intermediary Performance. Journal of Management Studies, 37(2): 167-184.

Perry, A.C. 1990. The Evolution of the U.S. International Trade Intermediary in the 1980s: A Dynamic Model. Journal of International Business Studies, 21(1): 133-153.

Petricevic, O., \& Teece, D.J. 2019. The structural reshaping of globalization: Implications for strategic sectors, profiting from innovation, and the multinational enterprise. Journal of International Business Studies, 50: 1487-1512.

Popp, A. 2000. Swamped in information but starved of data: information and intermediaries in clothing supply chains. Supply Chain Management: An International Journal, 5(3): 151-161.

Pratt, M.G. 2008. Fitting Oval Pegs into Round Holes: Tensions in Evaluating and Publishing Qualitative Research in Top-Tier North American Journals. Organizational Research Methods, 11(3): 481-509.

Ramstrom, J. 2008. Inter-organizational meets interpersonal: An exploratory study of social capital processes in relationships between Northern European and ethnic Chinese firms. Industrial Marketing Management, 37(5): 502-512.

Reuer, J. J., \& Ragozzino, R. 2014. Signals and international alliance formation: The roles of affiliations and international activities. Journal of International Business Studies, 45(3): 321337.

Salmi, A. 2006. Organising international supplier relations: An exploratory study of Western purchasing in China. Journal of Purchasing and Supply Management, 12: 197-208.

Sartor, M., Orzes, G., Nassimbeni, G., Jia, F., \& Lamming, R. 2014. International purchasing offices: Literature review and research directions. Journal of Purchasing \& Supply Management, 20(1): $1-17$.

Solberg, C.A. 2008. Product Complexity and Cultural Distance Effects on Managing International Distributor Relationships: A Contingency Approach. Journal of International Marketing, 16(3): 57-83.

Trent, R.J., \& Monczka, R.M. 2003. International Purchasing and Global Sourcing -What Are the Differences? Journal of Supply Chain Management, 39(4): 26-37.

Tsang, E.W.K. 1998. Can guanxi be a source of sustained competitive advantage for doing business in China? The Academy of Management Executive, 12 (2): 64-73.

Tung, R., \& Stahl, G. 2018. The tortuous evolution of the role of culture in IB research: What we know, what we don't know, and where we are headed. Journal of International Business Studies $49,1167-1189$.

Vedel, M., \& Ellegaard, C. 2013. Supply risk management functions of sourcing intermediaries: an investigation of the clothing industry. Supply Chain Management: An International Journal, 18: 509-522.

Wang, Y., Jia., F., Schoenherr, T., \& Gong, Y. 2018. Supply Chain-Based Business Model Innovation: The Case of a Cross-Border E-Commerce Company. Sustainability, 10(12): 4362.

Williamson, O.E. 1996. The mechanisms of governance. New York, NY: Ox ford University Press. 
Witt, M. A. 2019a. China's challenge: Geopolitics, de-globalization, and the future of Chinese business. Management and Organization Review, 15(4): 687-704.

Witt, M. A. 2019b. De-globalization: Theories, predictions, and implications for international business research. Journal of International Business Studies, 50(7): 1053-1077

Witt, M., Li, P.P., Välikangas, L., \& Lewin, A. 2021. De-globalization and Decoupling: Game Changing Consequences. Management and Organization Review, 17(1): 6-15.

Yin, R. K. 2009. Case study research: Design and methods. London: Sage Publications.

Zhang, K. H. (Ed.). 2006. China as the world factory. (1st ed.). London: Routledge. 

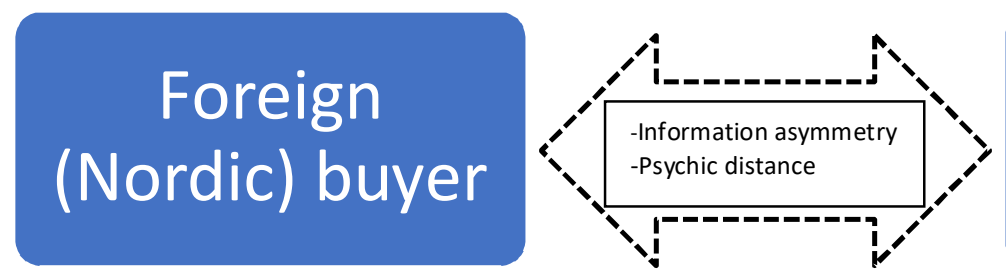

\section{Chinese supplier}

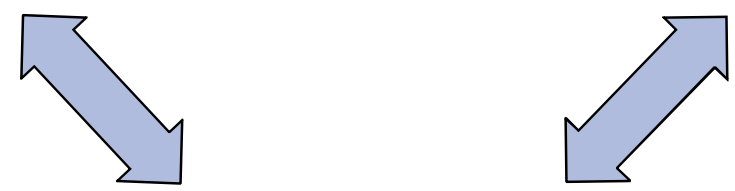

\section{Intermediary}

Activities (e.g. information sharing, signaling)

Continuity of the position

Figure 1 Analytic framework 


\section{First-order Categories}

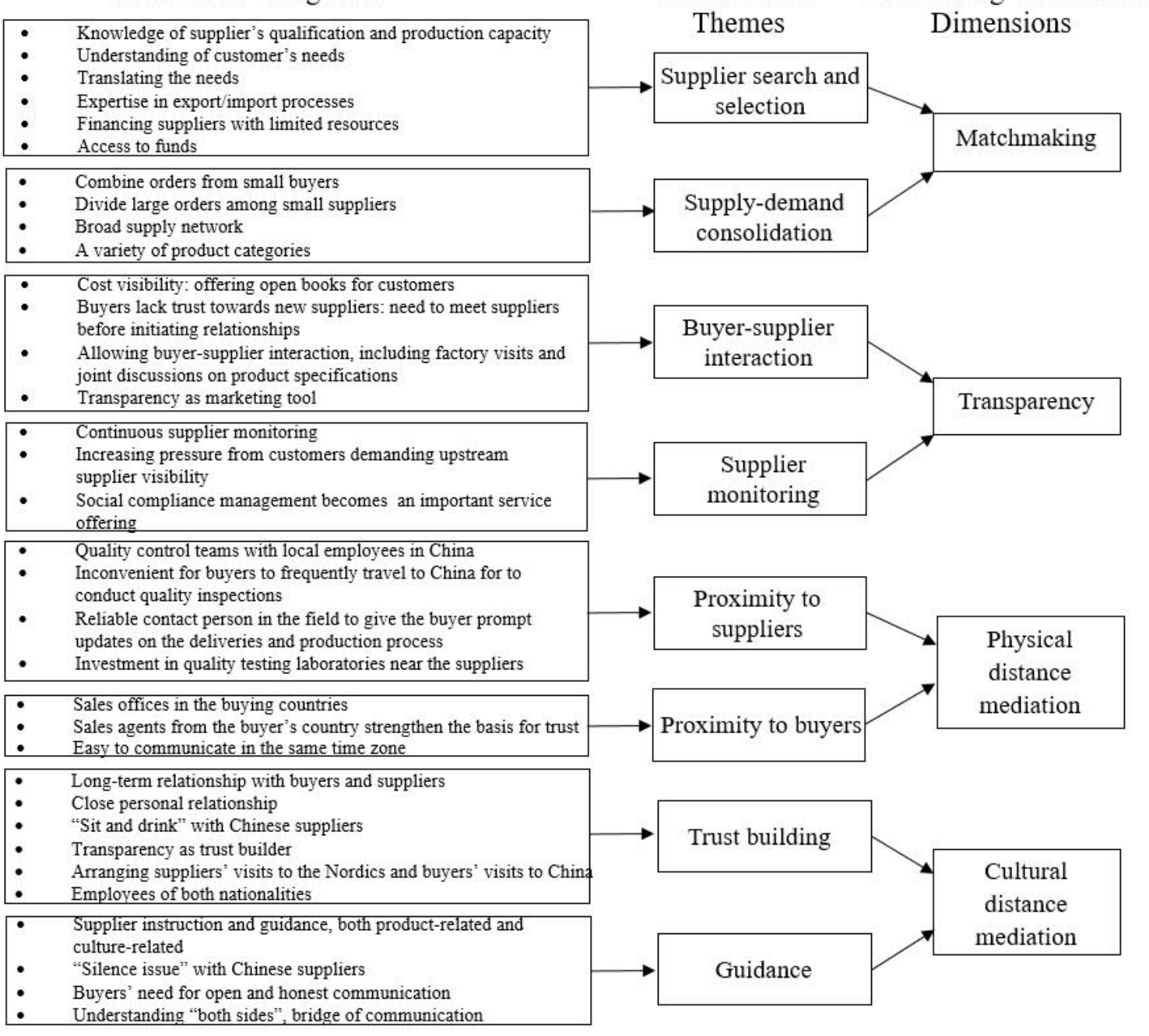

Figure 2 The data structure 
Table I

A comparison of the sampled Nordic and Chinese intermediaries

\begin{tabular}{|l|l|l|}
\hline & Nordic intermediaries (6) & Chinese intermediaries (7) \\
\hline Company size & Micro/Small/Medium (6 of 6) & Large (7 of 7) \\
\hline $\begin{array}{l}\text { Ownership } \\
\text { type }\end{array}$ & Private (6 of 6) & $\begin{array}{l}\text { State-owned (4 of 7) } \\
\text { Private (3 of 7) }\end{array}$ \\
\hline Take title & Typically No (4 of 6) & Typically Yes (6 of 7) \\
\hline Channel focus & Import/Sourcing (6 of 6) & Export/Selling (7 of 7) \\
\hline
\end{tabular}

\section{Table II}

An overview of the sampled companies and interviews

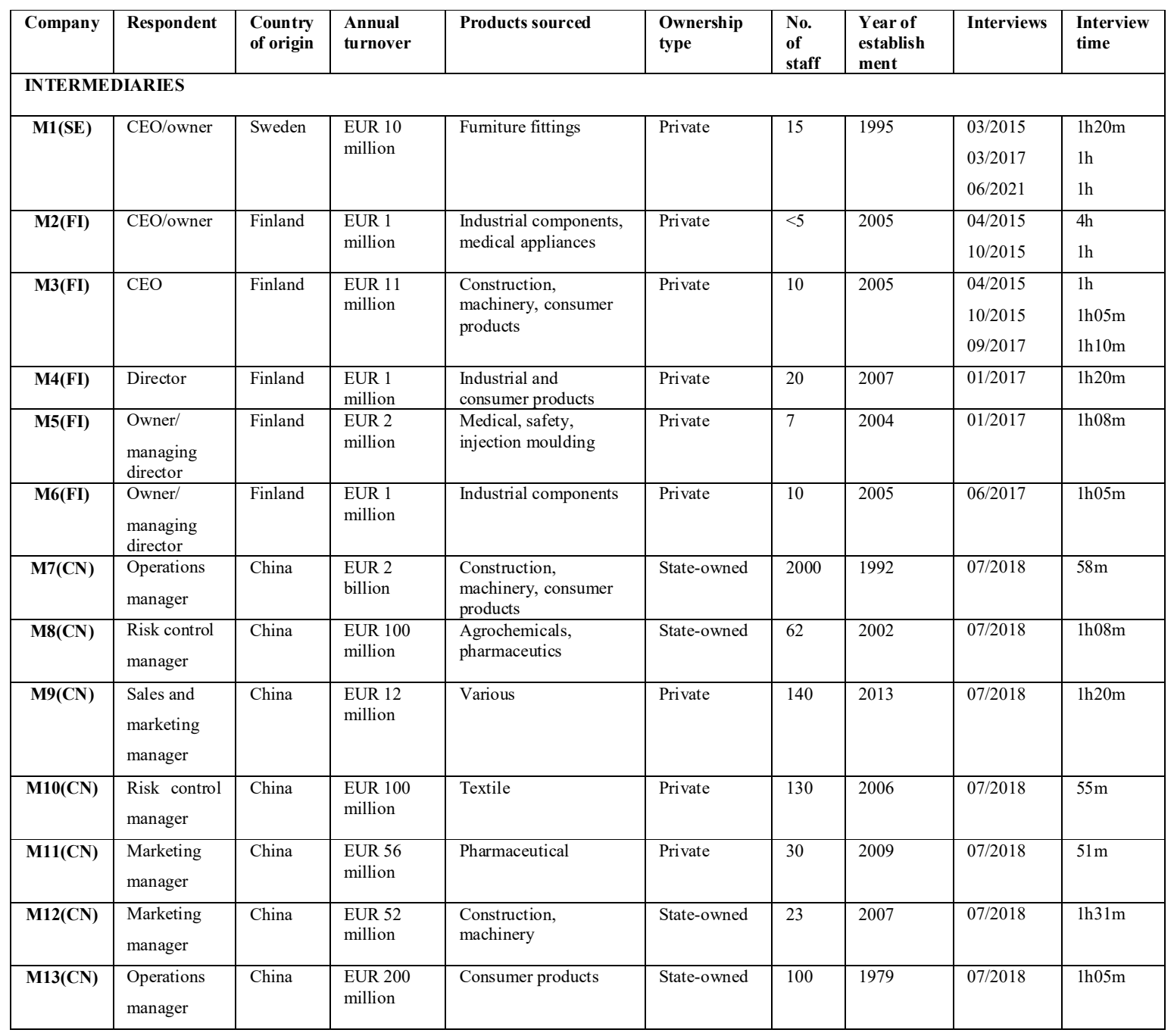




\begin{tabular}{|c|c|c|c|c|c|c|c|c|c|}
\hline \multicolumn{10}{|c|}{ OTHER INFORMANTS } \\
\hline S1(CN) & $\begin{array}{l}\text { Operations } \\
\text { manager }\end{array}$ & China & $\begin{array}{l}\text { EUR } 17 \\
\text { million }\end{array}$ & $\begin{array}{l}\text { Machining, punching, } \\
\text { casting, plastic } \\
\text { injection, fabrications }\end{array}$ & Private & 30 & 1998 & $\begin{array}{l}05 / 2015 \\
10 / 2015\end{array}$ & $\begin{array}{l}\mathrm{h} 05 \mathrm{~m} \\
1 \mathrm{~h} 02 \mathrm{~m}\end{array}$ \\
\hline B2(FI) & $\mathrm{COO}$ & Finland & $\begin{array}{l}\text { EUR } 6 \\
\text { million }\end{array}$ & Brand clothing & Private & 13 & 2001 & $03 / 2017$ & $1 \mathrm{~h} 20 \mathrm{~m}$ \\
\hline
\end{tabular}

\section{Table III}

The data sources for the study

\begin{tabular}{|l|l|}
\hline Type of data & Quantity \\
\hline Interviews & $\begin{array}{l}17 \text { interviews (in total 22 hours) with 13 intermediaries } \\
5 \text { interviews with other informants (in total 5 hours): 2 buyers (in } \\
\text { Finland and Sweden, respectively), 1 supplier and 1 industry expert } \\
\text { (in China) }\end{array}$ \\
\hline $\begin{array}{l}\text { Additional questions via } \\
\text { email exchanges }\end{array}$ & $\begin{array}{l}\text { Email exchanges with 2 intermediaries, 1 supplier and 1 industry } \\
\text { expert (in China) }\end{array}$ \\
\hline Company websites & 131 webpages \\
\hline Company documents & 73 pages of company reports and presentations \\
\hline Media materials & 11 pages of news articles \\
\hline
\end{tabular}




\section{Table IV}

Pre-contractual and post-contractual problems, and intermediaries' informational activities with illustrative quotes from the interviews

\begin{tabular}{|c|c|c|c|}
\hline $\begin{array}{l}\text { Pre- } \\
\text { contractual } \\
\text { problems }\end{array}$ & Illustrative quotes & $\begin{array}{l}\text { Pre- } \\
\text { contractual } \\
\text { activities }\end{array}$ & Illustrative quotes \\
\hline \multirow[t]{3}{*}{$\begin{array}{l}\text { Lack of } \\
\text { information } \\
\text { about suppliers' } \\
\text { compatibility }\end{array}$} & \multirow{3}{*}{$\begin{array}{l}\text { "We need the agent to focus on finding good pairs. So they } \\
\text { need to find a suitable size partner, which is interested in } \\
\text { making } 500 \text { pieces, and it needs to be the same level more or } \\
\text { less. That is a key thing." B1(FI) } \\
\text { "It has changed since I started to work } 20 \text { years ago. From } \\
\text { the beginning, it was enough to say that I have a supplier in } \\
\text { China, and then the customer will jump high and say 'Wow! } \\
\text { He has connections in China! Let's buy!' All the prices were } \\
\text { competitive. The world is much smaller today. It's so much } \\
\text { easier with email, with Alibaba, with internet, with cheap } \\
\text { airline tickets, with the good infrastructure in China, with } \\
\text { good high-speed train... today it's not enough to say 'I have } \\
\text { a supplier in China, would you like to buy?' You have to add } \\
\text { much more to your product." M1(SE) }\end{array}$} & \multirow[t]{3}{*}{ Matchmaking } & $\begin{array}{l}\text { - Supplier search and selection } \\
\text { "We help overseas customers access to Chinese suppliers, and help Chinese } \\
\text { suppliers internationalise, especially with our financing. Therefore, we } \\
\text { bridge companies from China and the rest of the world." M12 (CN) } \\
\text { "In our sourcing job we pay high attention to the fact that customer and } \\
\text { supplier must fit together regarding company size, quality, working way, } \\
\text { etc." M1(SE) }\end{array}$ \\
\hline & & & $\begin{array}{l}\text { - Supply-demand consolidation } \\
\text { "Our customers can benefit from the advantages of a large company and } \\
\text { still keep the customer service and attention as that of a small and dedicated } \\
\text { company. Large combined purchase volumes from our suppliers gives us } \\
\text { attractive product prices, low minimum order quantity requirements and } \\
\text { competitive shipping rates." M1(SE) }\end{array}$ \\
\hline & & & $\begin{array}{l}\text { "Now almost all the jackets are done by M4(FI) come from one factory. So } \\
\text { that we have a better package, and it's also easier for us to communicate, } \\
\text { because we only communicate with the agent. Since everything is coming } \\
\text { from one factory, and we are a better client for that factory with our bigger } \\
\text { combined orders. And that way, if we have one style that is selling well, } \\
\text { perhaps other styles selling less, then we can combine fabric and get those } \\
\text { small ones produced as well. So it gives us that kind advantages." B1(FI) }\end{array}$ \\
\hline $\begin{array}{l}\text { Lack of } \\
\text { information } \\
\text { about suppliers' } \\
\text { true } \\
\text { qualification }\end{array}$ & $\begin{array}{l}\text { "Our buyers know English, it's easy for them to travel to } \\
\text { China, and find hundreds of suppliers. But which one is the } \\
\text { good one? Is that a trading house, or is that a factory? Can I } \\
\text { trust on this? People don't want "just try', they want this kind } \\
\text { of security." M4(FI) } \\
\text { "Now sustainability and environmental issues are becoming } \\
\text { much more recognised and required... we try to be more } \\
\text { open in our communication and we also get a lot of request } \\
\text { from our customers about our product origins." B1(FI) }\end{array}$ & Transparency & $\begin{array}{l}\text { - Buyer-supplier interaction } \\
\text { "It's something the buyers really need [buyer-supplier interaction]. For } \\
\text { example, big companies like C-Group, they want transparency. To see who } \\
\text { are the players, how are the factories alike. In fact, we encourage all our } \\
\text { customers come to the sourcing market, to look around. Because normally } \\
\text { they get more idea when they see a nice show room, factories. It's a good } \\
\text { marketing tool. We have no reason to hide. Because the buyer anyway pay } \\
\text { their bills to the suppliers. It's also easier to solve problems not only } \\
\text { through us. Also for big companies, we say that working with us you are } \\
\text { buying directly from China, you know the supplier, you pay them, we are } \\
\text { just service provider to help you that everything runs smoothly." M4(FI) } \\
\text { "We take our customers to visit the suppliers' factories and check the } \\
\text { production process. I'm not worried about being skipped, because we can } \\
\text { provide a wide selection of products, which one single factory cannot. In }\end{array}$ \\
\hline
\end{tabular}




\begin{tabular}{|c|c|c|c|}
\hline & & & $\begin{array}{l}\text { fact, some customers work with us at the same time working with some of } \\
\text { our suppliers directly. The purpose is different." M10 (CN) }\end{array}$ \\
\hline & & & $\begin{array}{l}\text { - Supplier monitoring } \\
\text { "Nowadays, more branded company with premium quality want to assure } \\
\text { that the quality is good and stable, and the suppliers comply with social and } \\
\text { environmental issues. Then they need someone to take care of it. In our } \\
\text { Shanghai office we have a social compliance and environment team whose } \\
\text { tasks are to evaluate, monitor and report on social compliance through } \\
\text { factory visits. This unit also helps our staff in all matters concerning social } \\
\text { compliance in China." M4(FI) }\end{array}$ \\
\hline $\begin{array}{l}\text { Post- } \\
\text { contractual } \\
\text { problems }\end{array}$ & Illustrative quotes & $\begin{array}{l}\text { Post- } \\
\text { contractual } \\
\text { activities }\end{array}$ & Illustrative quotes \\
\hline \multirow[t]{2}{*}{$\begin{array}{l}\text { Lack of } \\
\text { information } \\
\text { about suppliers' } \\
\text { daily operations }\end{array}$} & \multirow[t]{2}{*}{$\begin{array}{l}\text { "It's important to have someone there [in China] as our } \\
\text { respondent, so he or she knows what's going on." B2(FI) } \\
\text { "We need them because they are located near many of our } \\
\text { suppliers and factories in China, so they can check the } \\
\text { suppliers, quality, and delivery." B2(SE) }\end{array}$} & \multirow[t]{2}{*}{$\begin{array}{l}\text { Physical } \\
\text { distance } \\
\text { mediation }\end{array}$} & $\begin{array}{l}\text { - Proximity to suppliers } \\
\text { "They are located in China or Asia, if there is some problem at the factory } \\
\text { or we have some quality problems, it's easy to have one of the staff by the } \\
\text { agency to go to the factory and check and hopefully fix the problem in an } \\
\text { easy way." B2(SE) } \\
\text { "We have Chinese in the field and me here. So we see both sides. I'm used } \\
\text { to understand how European people think and I have Chinese people who } \\
\text { understand how Chinese people think. It's easy and quick for me to get to } \\
\text { the customers, visit them and discuss everything with them. So it's an } \\
\text { advantage of 'being present". M1(SE) }\end{array}$ \\
\hline & & & $\begin{array}{l}\text { - Proximity to buyers } \\
\text { "In Finland, for a pure Chinese intermediary, it may be difficult to have this } \\
\text { kind of trust from Finnish customers. Imaging you come from } 9000 \\
\text { kilometers other side of the world, try to sell and trade good to you, then } \\
\text { the next day comes a Finnish guy, which one you trust, which one you } \\
\text { prefer?" M6 (FI) } \\
\text { "We understand the customers' needs in Europe or Nordic world. Because } \\
\text { the requirements are quite different in Europe than in China. And also the } \\
\text { Asian culture compared to European culture it is much different, not only } \\
\text { about the quality, but also given how people think about different issues." } \\
\text { M5 (FI) }\end{array}$ \\
\hline $\begin{array}{l}\text { Lack of } \\
\text { information } \\
\text { about suppliers' } \\
\text { perception of } \\
\text { the objectives }\end{array}$ & $\begin{array}{l}\text { "The Chinese sometimes have trouble understanding one } \\
\text { white is not the same as the other white." M3(FI) } \\
\text { "It's completely different thing when you buy from Europe } \\
\text { like Germany, Italy, Spain, you can just send PO with } \\
\text { drawings to the suppliers and then they will deliver the parts } \\
\text { with good quality. But in China, not so much. You have to }\end{array}$ & $\begin{array}{l}\text { Cultural } \\
\text { distance } \\
\text { mediation }\end{array}$ & $\begin{array}{l}\text { - Trust building } \\
\text { "Our customers trust our service quality because they have been working } \\
\text { with us for a long time." M11 (CN) } \\
\text { "It [long-term relationship] gives you this kind of continuity, gives us } \\
\text { assurance, even though you make a mistake, we will still continue working } \\
\text { with them. Especially since we are a brand company, we appreciate } \\
\text { continuity, it's everything. It gives a promise of the next stage." B2(FI) }\end{array}$ \\
\hline
\end{tabular}




\begin{tabular}{|c|c|c|}
\hline & \multirow[t]{2}{*}{$\begin{array}{l}\text { be very work orientated and pay attention to every detail to } \\
\text { make sure you will get good quality." } \mathrm{M} \text { (FI) }\end{array}$} & $\begin{array}{l}\text { "We have dinners so they would know you. This deepens the relationship } \\
\text { little by little. During my } 10 \text { years' experience doing business with the } \\
\text { Chinese, the first time you meet a new company, they don't ask what's your } \\
\text { company's turnover, they ask who you know, what's your guanxi. It is so } \\
\text { important who you know, who you work with, especially in China. It's } \\
\text { related with trust: why should I work with you? What can I benefit from } \\
\text { you?" M1(FI) }\end{array}$ \\
\hline & & $\begin{array}{l}\text { - Guidance } \\
\text { "Knowledge sharing is a necessary act in order to reach the European } \\
\text { quality standards." M3(FI) } \\
\text { "We understand the local environment and companies, have good } \\
\text { relationships with the government and shipping companies, as well as } \\
\text { understand the needs of Nordic customers. In a way, we are playing the role } \\
\text { of a 'connector'." M7 (CN) }\end{array}$ \\
\hline
\end{tabular}




\section{Appendix 1}

\section{Table AI}

Sourcing intermediary activities as described in the intermediary literature

\begin{tabular}{|c|c|c|c|c|c|c|c|c|c|}
\hline & $\begin{array}{l}\text { Sourcing } \\
\text { intermediar } \\
\text { y activities }\end{array}$ & $\begin{array}{l}\text { Fung \& } \\
\text { Chen, } \\
2010\end{array}$ & $\begin{array}{l}\text { Jia et al., } \\
2014 \mathrm{~b}\end{array}$ & $\begin{array}{l}\text { Monczk } \\
\text { a \& } \\
\text { Trent, } \\
1991\end{array}$ & $\begin{array}{l}\text { Nassimb } \\
\text { eni \& } \\
\text { Sartor, } \\
2007\end{array}$ & $\begin{array}{l}\text { Peng \& } \\
\text { York, } \\
2001\end{array}$ & $\begin{array}{l}\text { Perry, } \\
1990\end{array}$ & $\begin{array}{l}\text { Sartor et } \\
\text { al., } 2014\end{array}$ & $\begin{array}{l}\text { Vedel \& } \\
\text { Ellegaar } \\
\text { d, } 2013\end{array}$ \\
\hline \multirow[t]{9}{*}{$\begin{array}{l}\text { Supplier } \\
\text {-related } \\
\text { activities }\end{array}$} & $\begin{array}{l}\text { Creating } \\
\text { new supply } \\
\text { markets }\end{array}$ & & & & & $\mathrm{X}$ & $\mathrm{X}$ & & $\mathrm{X}$ \\
\hline & $\begin{array}{l}\text { Operating } \\
\text { high risk } \\
\text { markets }\end{array}$ & & & & & & $\mathrm{X}$ & & $\mathrm{X}$ \\
\hline & $\begin{array}{l}\text { Supplier } \\
\text { search/select } \\
\text { ion }\end{array}$ & $\mathrm{X}$ & $\mathrm{X}$ & $\mathrm{X}$ & $\mathrm{X}$ & $\mathrm{X}$ & $\mathrm{X}$ & $\mathrm{X}$ & $\mathrm{X}$ \\
\hline & $\begin{array}{l}\text { Supplier } \\
\text { monitoring }\end{array}$ & $\mathrm{X}$ & $\mathrm{X}$ & $\mathrm{X}$ & $\mathrm{X}$ & $\mathrm{X}$ & $\mathrm{X}$ & $\mathrm{X}$ & $\mathrm{X}$ \\
\hline & $\begin{array}{l}\text { Supplier } \\
\text { relationship } \\
\text { management }\end{array}$ & $\mathrm{X}$ & $\mathrm{X}$ & & $\mathrm{X}$ & & $\mathrm{X}$ & $\mathrm{X}$ & $\mathrm{X}$ \\
\hline & $\begin{array}{l}\text { CMT } \\
\text { coordination }\end{array}$ & & & & & & & & $\mathrm{X}$ \\
\hline & $\begin{array}{l}\text { Offer } \\
\text { analysis }\end{array}$ & & $\mathrm{X}$ & & & & & & \\
\hline & $\begin{array}{l}\text { Agreement } \\
\text { definition }\end{array}$ & & $\mathrm{X}$ & & & & & & \\
\hline & $\begin{array}{l}\text { Negotiation } \\
\text { (price, } \\
\text { payment } \\
\text { terms, } \\
\text { deliveries, } \\
\text { etc.) } \\
\end{array}$ & & $\mathrm{X}$ & $\mathrm{X}$ & $\mathrm{X}$ & $\mathrm{X}$ & & $\mathrm{X}$ & \\
\hline \multirow{5}{*}{$\begin{array}{l}\text { Product- } \\
\text { related } \\
\text { activities }\end{array}$} & $\begin{array}{l}\text { Quality } \\
\text { control }\end{array}$ & $\mathrm{X}$ & $\mathrm{X}$ & & & & & & $\mathrm{X}$ \\
\hline & $\begin{array}{l}\text { Supply/dem } \\
\text { and } \\
\text { consolidatio } \\
\mathrm{n}\end{array}$ & $\mathrm{X}$ & & & & & & & $\mathrm{X}$ \\
\hline & $\begin{array}{l}\text { Buying and } \\
\text { selling } \\
\text { goods traded }\end{array}$ & & & & $\mathrm{X}$ & $\mathrm{X}$ & $\mathrm{X}$ & & \\
\hline & $\begin{array}{l}\text { Procurement } \\
\text { of critical } \\
\text { raw } \\
\text { materials }\end{array}$ & & $\mathrm{X}$ & & & & & & \\
\hline & $\begin{array}{l}\text { Order } \\
\text { processing }\end{array}$ & & $\mathrm{X}$ & & & & & $\mathrm{X}$ & \\
\hline $\begin{array}{l}\text { Logistics } \\
\text {-related } \\
\text { activities } \\
\end{array}$ & $\begin{array}{l}\text { Securing } \\
\text { delivery } \\
\text { (incl. pre- }\end{array}$ & $\mathrm{X}$ & & & & & & & $\mathrm{X}$ \\
\hline
\end{tabular}




\begin{tabular}{|c|c|c|c|c|c|c|c|c|c|}
\hline & $\begin{array}{l}\text { booking } \\
\text { capacity, } \\
\text { hedging } \\
\text { suppliers) }\end{array}$ & & & & & & & & \\
\hline & $\begin{array}{l}\text { International } \\
\text { transport/log } \\
\text { istics } \\
\text { arrangement } \\
\end{array}$ & $\mathrm{X}$ & $X$ & $X$ & & $\mathrm{X}$ & $\mathrm{X}$ & $X$ & \\
\hline & $\begin{array}{l}\text { Inventory } \\
\text { holding/war } \\
\text { ehousing }\end{array}$ & $X$ & & & & & & & \\
\hline & $\begin{array}{l}\text { Customs } \\
\text { obligations }\end{array}$ & & & & & $\mathrm{X}$ & $\mathrm{X}$ & $\mathrm{X}$ & \\
\hline \multirow{3}{*}{$\begin{array}{l}\text { Knowled } \\
\text { ge- } \\
\text { related } \\
\text { activities }\end{array}$} & $\begin{array}{l}\text { Mediating } \\
\text { cultural } \\
\text { distance }\end{array}$ & & $\mathrm{X}$ & & & & & & $\mathrm{X}$ \\
\hline & $\begin{array}{l}\text { Product } \\
\text { development } \\
\text { and support }\end{array}$ & $X$ & $X$ & $\mathrm{X}$ & & & & $X$ & $\mathrm{X}$ \\
\hline & $\begin{array}{l}\text { Technical } \\
\text { support }\end{array}$ & $\mathrm{X}$ & $\mathrm{X}$ & $\mathrm{X}$ & $\mathrm{X}$ & & & $\mathrm{X}$ & \\
\hline \multirow[t]{2}{*}{$\begin{array}{l}\text { Other } \\
\text { activities }\end{array}$} & $\begin{array}{l}\text { Cost } \\
\text { visibility }\end{array}$ & & & & & & & & $\mathrm{X}$ \\
\hline & $\begin{array}{l}\text { Financial } \\
\text { support }\end{array}$ & & $\mathrm{X}$ & & & & $\mathrm{X}$ & $\mathrm{X}$ & \\
\hline
\end{tabular}

\section{Appendix 2}

\section{Table AII}

Intermediary studies

\begin{tabular}{|l|l|l|l|l|l|}
\hline Studies & Approach & $\begin{array}{l}\text { Theoretical } \\
\text { lens }\end{array}$ & Research focus & Context & $\begin{array}{l}\text { Perceptions of } \\
\text { intermediary }\end{array}$ \\
\hline $\begin{array}{l}\text { Monczka \& } \\
\text { Trent (1991) }\end{array}$ & Conceptual & TCE & $\begin{array}{l}\text { Developed a process model } \\
\text { for international sourcing }\end{array}$ & N/A & $\begin{array}{l}\text { Temporary global } \\
\text { sourcing strategy }\end{array}$ \\
\hline Popp (2000) & $\begin{array}{l}\text { Single case } \\
\text { study }\end{array}$ & TCE & $\begin{array}{l}\text { Proposed an explanation of } \\
\text { intermediation and its role as } \\
\text { information specialist }\end{array}$ & $\begin{array}{l}\text { UK clothing } \\
\text { industry }\end{array}$ & $\begin{array}{l}\text { Significant element } \\
\text { of many supply } \\
\text { chains; information } \\
\text { specialist }\end{array}$ \\
\hline Ellis (2001) & Survey & $\begin{array}{l}\text { Adaptive } \\
\text { strategy }\end{array}$ & $\begin{array}{l}\text { Proposed an evolutionary } \\
\text { model of trading companies } \\
\text { based on their adaptive } \\
\text { strategies }\end{array}$ & $\begin{array}{l}\text { Hong Kong } \\
\text { traders }\end{array}$ & $\begin{array}{l}\text { Highly } \\
\text { entrepreneurial } \\
\text { organisational entities } \\
\text { that are alert to new } \\
\text { and emerging } \\
\text { opportunities }\end{array}$ \\
\hline
\end{tabular}




\begin{tabular}{|c|c|c|c|c|c|}
\hline Ellis (2005) & Survey & TCE & $\begin{array}{l}\text { Demonstrated manufacturers' } \\
\text { perceptions of intermediary } \\
\text { performance and the } \\
\text { likelihood of their terminating } \\
\text { the arrangement }\end{array}$ & $\begin{array}{l}\text { Chinese } \\
\text { manufacturers }\end{array}$ & $\begin{array}{l}\text { Intermediaries will } \\
\text { eventually cease to } \\
\text { exist }\end{array}$ \\
\hline $\begin{array}{l}\text { Nassimbeni \& } \\
\text { Sartor (2007) }\end{array}$ & $\begin{array}{l}\text { Multiple } \\
\text { case studies }\end{array}$ & $\begin{array}{l}\text { International } \\
\text { sourcing } \\
\text { typology }\end{array}$ & $\begin{array}{l}\text { Developed a typology for } \\
\text { sourcing in China }\end{array}$ & $\begin{array}{l}\text { Italian firms } \\
\text { sourcing from } \\
\text { China }\end{array}$ & $\begin{array}{l}\text { Sourcing mode for } \\
\text { SMEs }\end{array}$ \\
\hline Ellis (2010) & Survey & TCE & $\begin{array}{l}\text { Examined international trade } \\
\text { intermediaries' role in the } \\
\text { transfer of marketing } \\
\text { knowledge across borders }\end{array}$ & $\begin{array}{l}\text { Chinese } \\
\text { manufacturers }\end{array}$ & $\begin{array}{l}\text { Valuable role in } \\
\text { transferring } \\
\text { marketing knowledge } \\
\text { to manufacturers }\end{array}$ \\
\hline $\begin{array}{l}\text { Fung \& Chen } \\
\text { (2010) }\end{array}$ & Survey & $\begin{array}{l}\text { SCM } \\
\text { capabilities }\end{array}$ & $\begin{array}{l}\text { Examined the impact of SCM } \\
\text { capabilities on the } \\
\text { performance of international } \\
\text { trade intermediaries }\end{array}$ & $\begin{array}{l}\text { Hong Kong } \\
\text { intermediaries }\end{array}$ & $\begin{array}{l}\text { Integrator of } \\
\text { geographically } \\
\text { dispersed value-chain } \\
\text { activities }\end{array}$ \\
\hline $\begin{array}{l}\text { Vedel \& } \\
\text { Ellegaard } \\
(2013)\end{array}$ & Interviews & $\begin{array}{l}\text { Supply risk } \\
\text { management }\end{array}$ & $\begin{array}{l}\text { Identified different sourcing } \\
\text { intermediary types based on } \\
\text { risk management functions }\end{array}$ & $\begin{array}{l}\text { Danish } \\
\text { clothing } \\
\text { industry }\end{array}$ & $\begin{array}{l}\text { Risk-reducing; } \\
\text { Value-creating }\end{array}$ \\
\hline $\begin{array}{l}\text { Jia et al. } \\
(2014 b)\end{array}$ & $\begin{array}{l}\text { Multiple } \\
\text { case studies }\end{array}$ & Role theory & $\begin{array}{l}\text { Developed a role-based } \\
\text { evolution model for IPOs }\end{array}$ & $\begin{array}{l}\text { Nordic firms' } \\
\text { IPOs in China }\end{array}$ & $\begin{array}{l}\text { Early stage; low } \\
\text { importance to parent } \\
\text { company }\end{array}$ \\
\hline
\end{tabular}

\section{Appendix 3}

\section{Table AII}

Interview questions

\section{Questions for intermediaries}

1. What services does your company offer to the customers?

2. Are there any major changes in your company's history (e.g. structure, services offered)? If yes, can you describe them?

3. Who do you represent (customer, supplier, independent)?

4. Could you describe how does your company add value to the partners?

5. Do you connect your suppliers with buyers? Why or why not? If yes, what does the supplierbuyer interaction include?

6. Has the current pandemic impacted your company? If yes, how? If no, why? 


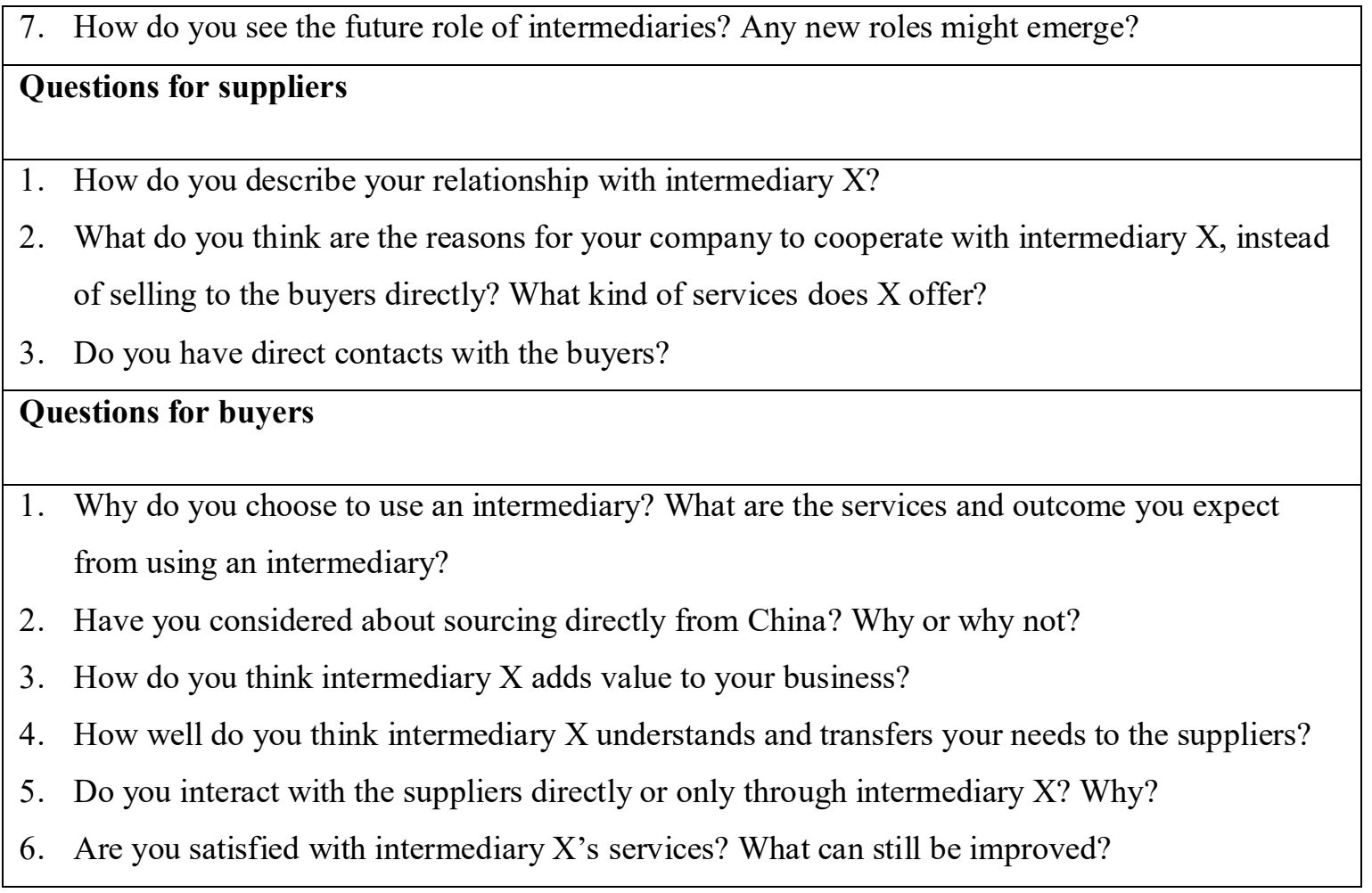

